$\xi_{p}=\mathbf{z}$

\title{
Estimation of direct normal irradiance under various sky conditions in data sparse tropical ecological zones in Nigeria
}

\author{
Nwokolo Samuel Chukwujindu *, Ogbulezie Julie C \\ Department of Physics, Faculty of Physical Sciences, University of Calabar, Nigeria, P.O. Box 2892, Calabar, Nigeria \\ *Corresponding author E-mail: nwokolosc@stud.unical.edu.ng
}

\begin{abstract}
In this study, models for estimating direct normal irradiance $\left(\mathrm{H}_{\mathrm{b}}\right)$ under various sky conditions in data sparse tropical ecological zones in Nigeria were fitted. The evaluated values of clearness index indicate that the prevailing sky condition in the southern tropical zones is heavily overcast while the northern zones experience partly overcast under all sky conditions. From the analyses of the influences of clearness index on $\mathrm{H}_{b}$, it was observed that higher values of $\mathrm{H}_{\mathrm{b}}$ were recorded in the far north zone of Sahel savannah (FNZSS) of Sokoto while lower values were registered in the far south zone of mangrove swamp of Port Harcourt revealing an increasing trend from FSZMS to FNZSS due to the trends in cloudiness and associated atmospheric moisture with the movement through the Hadley cell calculation system along the equatorial line. The regression correlation models developed from the model performance test indicates that the proposed models could be used to estimate $\mathrm{H}_{\mathrm{b}}$ accurately between latitude 4 to $10^{\circ} \mathrm{N}$, that is, mangroves swamp and Guinea savannah tropical zones in Nigeria and other locations with comparable sky conditions.
\end{abstract}

Keywords: Decomposition Model; Equatorial Line; Direct Transmittance; Clearness Index; Extraterrestrial Solar Radiation.

\section{Introduction}

Direct normal irradiance $\left(\mathrm{H}_{\mathrm{b}}\right)$ is the component of global horizontal irradiation $(\mathrm{H})$ received per unit area by a surface that is perpendicular (or normal) to the rays that come in a straight line from the direction of the sun at its current position in the sky. This radiometric flux is of particular interest to concentrating solar thermal installations and installations that track the position of the sun such as concentrating solar power (CSP) systems, parabolic dish, parabolic trough, Linear-Fresnel, or solar tower and concentrating photovoltaic (CPV) systems. The accurate determination and clear understanding of the $\mathrm{H}_{\mathrm{b}}$ parameters is required for many applications such as meteorology, radiation and energy budgets, climatology, water treatment process, heating and natural lighting, agriculture, forestry, renewable energy, design and production of solar energy systems, building of renewable power plants and a good evaluation of thermal environment within building. In spite of the enormous significance of $\mathrm{H}_{\mathrm{b}}$, there is no standard weather station capable to measure this radiation component in Nigeria and often there is no data available in the location of interest except National Aeronautics and Space Administration (NASA) atmospheric science data [1] among others satellite radiometric agencies across the globe. To overcome these problems, different estimation models have been proposed in different locations across the globe [215].

Considering the great importance of the $\mathrm{H}_{\mathrm{b}}$ in the design of solarenergy systems requiring solar radiation tracking, such as highintensity solar cells and high-temperature heat engines, emphasis is often put on modeling the $\mathrm{H}_{\mathrm{b}}$ component. Basically, there are two categories of $\mathrm{H}_{\mathrm{b}}$ models available in literature: decomposition and parametric or atmospheric transmittance models. Parametric models require detailed information of atmospheric parameters or conditions such as type, amount and distribution of clouds consisting of could cover, precipitation water content, atmospheric turbidity, and sunshine fraction [3], [5-7], [11], [16-18]. On the other hand, decomposition models are used to estimate $\mathrm{Hb}$ from $\mathrm{H}$ and extraterrestrial solar radiation $\left(\mathrm{H}_{\mathrm{o}}\right)$ data [2-3], [8-10], [14-15], [19]. Battles et al. [20] recommended decomposition models, which are based on the correlation between the clearness index and direct fraction or direct transmittance where there are no precise information or data of atmospheric turbidity coefficient, precipitable water content and cloud cover. In this research, decomposition type models employing direct transmittance at various sky conditions were used to determine the influence of cloudiness on $\mathrm{H}_{\mathrm{b}}$ component in six tropical ecological zones in Nigeria. This will produce $\mathrm{H}_{\mathrm{b}}$ data for a baseline for further scientific, environmental and atmospheric research without the substantial cost of the instrumentation network that would otherwise be needed.

\section{Materials and methods}

\subsection{Acquisition of data and study area}

The long term monthly mean daily direct normal irradiance $\left(\mathrm{Hb}_{\mathrm{b}}\right)$, global solar radiation on the horizontal surface $(\mathrm{H})$, clearness index for cloudless sky $\left(\mathrm{H} / \mathrm{H}_{\mathrm{o}}\right)$ for the period of 1983-2005 for the selected state capitals and locations whose tropical ecological zones, coordinates and elevations listed in Table 1 and Fig. 1 were obtained from the National Aeronautics and Space Administration (NASA) atmospheric science data center [1]. The $\mathrm{H}_{\mathrm{b}}$ and $\mathrm{H}$ data measured in $\mathrm{kwhm}^{-2} \mathrm{day}^{-1}$ were converted to $\mathrm{MJm}^{-2} \mathrm{day}^{-1}$ using a 
factor of 3.6. The details about the study area are found in Nwokolo and Ogbulezie [21].

Table 1: States, State Capitals, Coordinates and Tropical Ecological Zones for the Selected Stations in Nigeria

\begin{tabular}{llllll} 
& Table 1: States, State Capitals, Coordinates and Tropical Ecological Zones for the Selected Stations in Nigeria \\
\hline States & State & $\begin{array}{l}\text { Latitude } \\
\text { (Degree North) }\end{array}$ & $\begin{array}{l}\text { Longitude Elevation } \\
\text { (Degree East) }\end{array}$ & $\begin{array}{l}\text { Tropical Ecological } \\
\text { (Meters) }\end{array}$ & Zones \\
\hline Rivers & Papitals & 4.75 & 7.00 & 117 & Mangrove Swamp \\
Imo & Oort Harcourt & 5.485 & 7.035 & 176 & Mangrove Swamp \\
Oyo & Ibadan & 7.378 & 3.947 & 183 & Tropical Rain Forest \\
FCT & Abuja & 9.067 & 7.483 & 484 & Guinea Savannah \\
Borno & Maiduguri & 11.85 & 13.16 & 377 & Sudan Savannah \\
Sokoto & Sokoto & 13.067 & 5.233 & 331 & Sahel Savannah \\
\hline
\end{tabular}

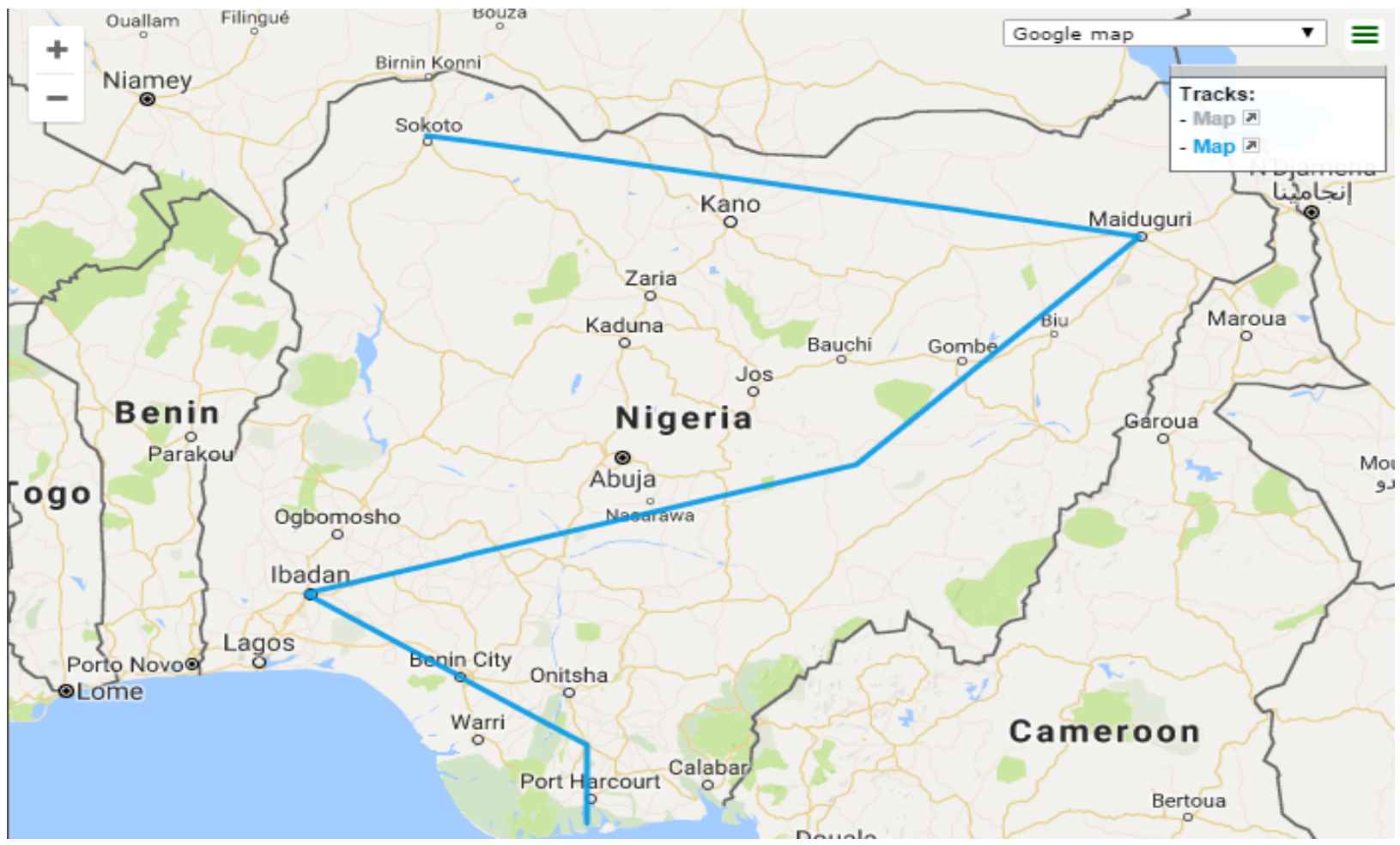

Fig. 1: Map of Nigeria Showing the Study Stations.

\subsection{Model development}

The modeling of $\mathrm{H}_{\mathrm{b}}$ involves the correlation of monthly mean daily $\mathrm{H}_{\mathrm{b}}$ to meteorological data such as extraterrestrial solar radiation $\left(\mathrm{H}_{\mathrm{o}}\right)$ and clearness index under all sky and cloudless sky conditions. Wenxian [14] established a linear model for correlating direct transmittance to clearness index while several researchers developed quadratic models using direct transmittance to clearness index [2-3], [9-10], [15]. In order to generate an appropriate mode for the study stations in addition to quadratic type model (model 1), two models based on the correlation between direct transmittance to clearness index: quadratic-exponential model (model 2) and linear-logarithmic (model 3) are proposed for all sky conditions and clear sky conditions (kt) in this research in the forms:

$$
\begin{aligned}
& \frac{H_{b}}{H_{o}}=b_{o}+b_{1}\left(\frac{H}{H_{o}}\right)+b_{2}\left(\frac{H}{H_{o}}\right)^{2} \\
& \frac{H_{b}}{H_{o}}=b_{o}+b_{1} \exp \left(\frac{H}{H_{o}}\right)+b_{2} \exp \left(\frac{H}{H_{o}}\right)^{2}
\end{aligned}
$$

$$
\frac{H_{b}}{H_{o}}=b_{o}+b_{1}\left(\frac{H}{H_{o}}\right)+b_{2} \log \left(\frac{H}{H_{o}}\right)
$$

Where bi represents the empirical coefficients, $\left(\mathrm{H} / \mathrm{H}_{\mathrm{o}}\right)$ is the clearness index, $\left(\mathrm{H}_{\mathrm{b}} / \mathrm{H}_{\mathrm{o}}\right)$ represents direct transmittance and $\mathrm{H}_{\mathrm{o}}$ representing the extraterrestrial solar radiation on the horizontal surface for all sky condition calculated using the following equations:

$$
H_{o}=\frac{24}{\pi} I S C\left(\begin{array}{l}
1 \\
+0.033 \cos \frac{360 n}{365}
\end{array}\right) \times\left(\begin{array}{c}
\cos \varphi \cos \delta \sin \omega_{S} \\
2 \pi \omega_{S} \\
+\frac{360}{36} \sin \varphi \sin \delta
\end{array}\right)
$$

Where $I_{S C}$ the solar constant, $\varphi$ is the latitude, $\delta$ is the solar declination and $\mathrm{n}$ the number of days of the year starting from first January. The daily extraterrestrial solar radiation is the solar radiation intercepted by horizontal surface during a day without the atmosphere. For a given month, the solar declination $(\delta)$ and the mean sunrise hour angle $\left(\omega_{s}\right)$ can be evaluated by the following equations (5) and (6) respectively.

$$
\delta=23.45 \sin \left[\frac{360(n+284)}{365}\right]
$$


$\omega_{s}=\cos ^{-1}[-\tan \delta \tan \varphi]$

A computer statistical software program (IBM SPSS 22) was used to compute the regression constants at $95 \%$ confidence level employed to obtaining the coefficient of determination $\left(\mathrm{R}^{2}\right)$.

\subsection{Estimation metrics}

To determine the error and performance of the predictive models, Willmott [22] suggested mean bias error (MBE) and root mean square error (RMSE) as good statistical indicator for evaluating the error between the observed and predicted (model) values. These relations are given as:

$$
\begin{aligned}
& M B E=\frac{1}{n} \sum_{i=1}^{n}\left(O_{i}-P_{i}\right) \\
& R M S E=\sqrt{\frac{1}{n} \sum_{i=1}^{n}\left(O_{i}-P_{i}\right)^{2}}
\end{aligned}
$$

Where $\mathrm{O}_{\mathrm{i}}$ and $\mathrm{P}_{\mathrm{i}}$ are the observed and predicted $\mathrm{H}_{\mathrm{b}}$ and other symbols retain their usual meaning.

\section{Results and discussions}

\subsection{Results}

The calculated values of the variation of atmospheric parameters such as extraterrestrial solar radiation $\left(\mathrm{H}_{\mathrm{o}}\right)$, observed and predicted (models) direct normal irradiance $\left(\mathrm{H}_{\mathrm{b}}\right)$ and clearness index for clear sky and all sky conditions in the six sites are presented in Table $2-7$ and Fig. 2 - 5. Their corresponding regression coefficients fitted and coefficient of determination employing direct transmittance and clearness index for all sky conditions and clear sky conditions are shown in Table 8, while scatter plot illustrating the observed and predicted values of $\mathrm{H}_{\mathrm{b}}$ are shown in Fig. $6-11$.

The associated error from the fitted models were evaluated using mean bias error (MBE) and root mean square error (RMSE) in order to determine the performance of the predictive models presented in Table 9 for Port Harcourt, Owerri, Ibadan, Abuja, Maiduguri and Sokoto.

Table 2: Monthly Mean Daily Values of Extraterrestrial Solar Radiation $\left(\mathrm{H}_{\mathrm{o}}\right)$ in $\mathrm{Mjm}^{-2} \mathrm{day}^{-1}$, Clearness Index $\left(\mathrm{k}_{\mathrm{t}}\right)$ Under All Sky Conditions and Clear Sky

\begin{tabular}{|c|c|c|c|c|c|c|c|c|c|c|}
\hline \multirow[t]{2}{*}{ Month } & \multirow[t]{2}{*}{$\mathrm{H}_{\mathrm{o}}$} & \multirow{2}{*}{$\begin{array}{l}\mathrm{k}_{\mathrm{t}} \\
\text { All Sky }\end{array}$} & \multirow{2}{*}{$\begin{array}{l}\mathrm{k}_{\mathrm{t}} \\
\text { Cloudless Sky }\end{array}$} & \multirow{2}{*}{$\begin{array}{l}\text { All Conditions } \\
\mathrm{Obs}_{\mathrm{b}}\end{array}$} & \multicolumn{3}{|c|}{ All Conditions } & \multicolumn{3}{|c|}{ Clear Sky Conditions } \\
\hline & & & & & Model 1 & Model 2 & Model 3 & Model 1 & Model 2 & Model 3 \\
\hline JAN & 34.52 & 0.54 & 0.53 & 18.68 & 17.97 & 18.34 & 18.19 & 16.01 & 16.05 & 16.03 \\
\hline FEB & 36.40 & 0.52 & 0.53 & 16.81 & 17.93 & 18.29 & 18.22 & 16.82 & 16.86 & 16.85 \\
\hline MAR & 37.66 & 0.46 & 0.55 & 12.82 & 14.00 & 14.32 & 14.42 & 17.43 & 17.47 & 17.46 \\
\hline APR & 37.40 & 0.44 & 0.58 & 11.74 & 12.61 & 12.93 & 13.00 & 8.33 & 8.37 & 8.36 \\
\hline MAY & 36.14 & 0.42 & 0.57 & 10.76 & 9.92 & 10.27 & 10.22 & 8.13 & 8.16 & 8.17 \\
\hline JUN & 35.21 & 0.36 & 0.55 & 7.92 & 6.44 & 6.78 & 6.74 & 10.50 & 10.58 & 10.48 \\
\hline JUL & 35.50 & 0.33 & 0.55 & 6.41 & 6.19 & 6.50 & 6.56 & 10.60 & 10.68 & 10.58 \\
\hline AUG & 36.58 & 0.34 & 0.57 & 6.59 & 7.14 & 7.50 & 7.40 & 8.25 & 8.28 & 8.29 \\
\hline SEP & 37.19 & 0.33 & 0.58 & 6.30 & 6.77 & 7.12 & 7.09 & 8.30 & 8.34 & 8.33 \\
\hline OCT & 36.50 & 0.36 & 0.59 & 7.96 & 7.45 & 7.82 & 7.69 & 8.87 & 8.98 & 8.83 \\
\hline NOV & 34.85 & 0.44 & 0.55 & 11.95 & 10.25 & 10.58 & 10.57 & 10.38 & 10.46 & 10.36 \\
\hline DEC & 33.77 & 0.53 & 0.54 & 17.75 & 15.61 & 15.91 & 15.93 & 12.50 & 12.58 & 12.47 \\
\hline AVE & 35.98 & 0.42 & 0.56 & 11.31 & 11.02 & 11.91 & 11.33 & 11.34 & 11.40 & 11.35 \\
\hline SUM & 431.71 & 5.07 & 6.69 & 135.68 & 132.26 & 136.34 & 136.01 & 136.14 & 136.80 & 136.22 \\
\hline
\end{tabular}
Conditions, Observed (Obs) and Predicted (Model 1, 2 and 3) Of Direct Normal Irradiance $\left(\mathrm{H}_{\mathrm{b}}\right)$ in $\mathrm{Mjm}^{-2} \mathrm{day}^{-1}$ for Port Harcourt

Table 3: Monthly Mean Daily Values of Extraterrestrial Solar Radiation $\left(\mathrm{H}_{\mathrm{o}}\right)$ in $\mathrm{Mjm}^{-2} \mathrm{day}^{-1}$, Clearness Index $\left(\mathrm{k}_{\mathrm{t}}\right)$ Under All Sky Conditions and Clear Sky

\begin{tabular}{|c|c|c|c|c|c|c|c|c|c|c|}
\hline \multirow[t]{2}{*}{ Month } & \multirow[t]{2}{*}{$\mathrm{H}_{\mathrm{o}}$} & \multirow{2}{*}{$\begin{array}{l}\mathrm{k}_{\mathrm{t}} \\
\text { All Sky }\end{array}$} & \multirow{2}{*}{$\begin{array}{l}\mathrm{k}_{\mathrm{t}} \\
\text { Cloudless Sky }\end{array}$} & \multirow{2}{*}{$\begin{array}{l}\text { All Conditions } \\
\text { Obs } \mathrm{H}_{\mathrm{b}}\end{array}$} & \multicolumn{3}{|c|}{ All Conditions } & \multicolumn{3}{|c|}{ Clear Sky Conditions } \\
\hline & & & & & Model 1 & Model 2 & Model 3 & Model 1 & Model 2 & Model 3 \\
\hline JAN & 34.09 & 0.58 & 0.54 & 21.19 & 21.44 & 21.47 & 21.37 & 15.63 & 15.67 & 15.63 \\
\hline FEB & 36.11 & 0.56 & 0.52 & 19.33 & 20.16 & 20.12 & 20.20 & 21.33 & 21.37 & 21.34 \\
\hline MAR & 37.55 & 0.51 & 0.55 & 15.84 & 16.80 & 16.74 & 16.90 & 15.13 & 15.17 & 15.15 \\
\hline APR & 37.51 & 0.49 & 0.58 & 14.33 & 15.12 & 15.07 & 15.18 & 10.50 & 10.54 & 10.52 \\
\hline MAY & 36.43 & 0.47 & 0.56 & 13.28 & 13.16 & 13.14 & 13.19 & 12.92 & 12.95 & 12.96 \\
\hline JUN & 35.57 & 0.44 & 0.55 & 11.66 & 11.06 & 11.06 & 11.03 & 14.33 & 14.37 & 14.35 \\
\hline JUL & 35.78 & 0.39 & 0.55 & 9.07 & 8.76 & 8.76 & 8.74 & 14.42 & 14.46 & 14.44 \\
\hline SEP & 37.19 & 0.38 & 0.59 & 8.46 & 8.85 & 8.84 & 8.85 & 9.42 & 9.50 & 9.39 \\
\hline OCT & 36.29 & 0.42 & 0.58 & 10.94 & 10.59 & 10.61 & 10.55 & 10.16 & 10.19 & 10.18 \\
\hline NOV & 34.45 & 0.51 & 0.53 & 16.06 & 15.10 & 15.04 & 15.18 & 17.95 & 18.00 & 17.95 \\
\hline DEC & 33.30 & 0.57 & 0.53 & 20.63 & 19.85 & 19.84 & 19.84 & 17.35 & 17.40 & 13.35 \\
\hline AVE & 35.92 & 0.47 & 0.56 & 14.08 & 14.10 & 14.08 & 14.12 & 14.12 & 14.16 & 14.13 \\
\hline SUM & 431.03 & 5.68 & 6.66 & 169.13 & 169.17 & 168.94 & 169.39 & 169.39 & 169.95 & 169.56 \\
\hline
\end{tabular}
Conditions, Observed (Obs) and Predicted (Model 1,2 And 3) of Direct Normal Irradiance ( $\mathrm{H}_{\mathrm{b}}$ ) in $\mathrm{Mjm}^{-2} \mathrm{day}^{-1} \mathrm{for}_{\mathrm{O}} \mathrm{Owerri}$ 
Table 4: Monthly Mean Daily Values of Extraterrestrial Solar Radiation $\left(\mathrm{H}_{\mathrm{o}}\right)$ in $\mathrm{Mjm}^{-2} \mathrm{day}^{-1}$, Clearness Index $\left(\mathrm{k}_{\mathrm{t}}\right)$ Under All Sky Conditions and Clear Sky Conditions, Observed (Obs) and Predicted (Model 1, 2 And 3) of Direct Normal Irradiance $\left(\mathrm{H}_{\mathrm{b}}\right)$ in $\mathrm{Mjm}^{-2} \mathrm{day}^{-1}$ for Ibadan

\begin{tabular}{|c|c|c|c|c|c|c|c|c|c|c|}
\hline \multirow[t]{2}{*}{ Month } & \multirow[t]{2}{*}{$\mathrm{H}_{\mathrm{o}}$} & \multirow{2}{*}{$\frac{\mathrm{k}_{\mathrm{t}}}{\text { All Sky }}$} & \multirow{2}{*}{$\begin{array}{l}\mathrm{k}_{\mathrm{t}} \\
\text { Cloudless Sky }\end{array}$} & \multirow{2}{*}{$\begin{array}{l}\text { All Conditions } \\
\text { Obs } \mathrm{H}_{\mathrm{b}}\end{array}$} & \multicolumn{3}{|c|}{ All Conditions } & \multicolumn{3}{|c|}{ Clear Sky Conditions } \\
\hline & & & & & Model 1 & Model 2 & Model 3 & Model 1 & Model 2 & Model 3 \\
\hline JAN & 33.23 & 0.60 & 0.55 & 22.18 & 22.49 & 22.47 & 22.42 & 16.00 & 15.95 & 16.00 \\
\hline FEB & 35.50 & 0.57 & 0.53 & 20.74 & 21.44 & 21.38 & 21.44 & 19.35 & 19.28 & 19.38 \\
\hline MAR & 37.08 & 0.53 & 0.55 & 18.07 & 18.99 & 18.91 & 19.02 & 17.85 & 17.79 & 17.86 \\
\hline APR & 37.44 & 0.50 & 0.56 & 15.70 & 16.74 & 16.66 & 16.76 & 15.64 & 15.61 & 15.62 \\
\hline MAY & 36.72 & 0.48 & 0.56 & 15.08 & 14.89 & 14.83 & 14.90 & 15.34 & 15.31 & 15.32 \\
\hline JUN & 36.00 & 0.45 & 0.54 & 12.74 & 12.46 & 12.41 & 12.44 & 18.86 & 18.78 & 18.89 \\
\hline JUL & 36.36 & 0.41 & 0.55 & 9.50 & 9.89 & 9.85 & 9.85 & 17.51 & 17.45 & 17.51 \\
\hline AUG & 37.08 & 0.38 & 0.57 & 7.96 & 8.17 & 8.12 & 8.15 & 12.35 & 12.31 & 12.33 \\
\hline SEP & 37.08 & 0.40 & 0.58 & 9.36 & 9.43 & 9.39 & 9.39 & 8.45 & 8.32 & 8.46 \\
\hline OCT & 35.78 & 0.45 & 0.57 & 13.64 & 12.38 & 12.33 & 12.36 & 11.92 & 11.88 & 11.90 \\
\hline $\mathrm{NOV}$ & 33.66 & 0.54 & 0.52 & 18.61 & 17.99 & 17.92 & 18.02 & 18.35 & 18.33 & 18.33 \\
\hline DEC & 32.36 & 0.59 & 0.55 & 22.10 & 21.11 & 21.07 & 21.07 & 15.58 & 15.53 & 15.58 \\
\hline AVE & 35.75 & 0.49 & 15.47 & 15.50 & 15.45 & 15.45 & 15.48 & 15.60 & 15.54 & 15.60 \\
\hline SUM & 428.29 & 5.90 & 6.63 & 185.69 & 185.96 & 185.34 & 185.81 & 187.18 & 186.52 & 187.18 \\
\hline
\end{tabular}

Table 5: Monthly Mean Daily Values of Extraterrestrial Solar Radiation $\left(\mathrm{H}_{\mathrm{o}}\right)$ in $\mathrm{Mjm}^{-2} \mathrm{day}^{-1}$, Clearness Index $\left(\mathrm{k}_{\mathrm{t}}\right)$ Under All Sky Conditions and Clear Sky Conditions, Observed (Obs) and Predicted (Model 1, 2 and 3) of Direct Normal Irradiance $\left(\mathrm{H}_{\mathrm{b}}\right)$ in $\mathrm{Mjm}^{-2} \mathrm{day}^{-1}$ for Abuja

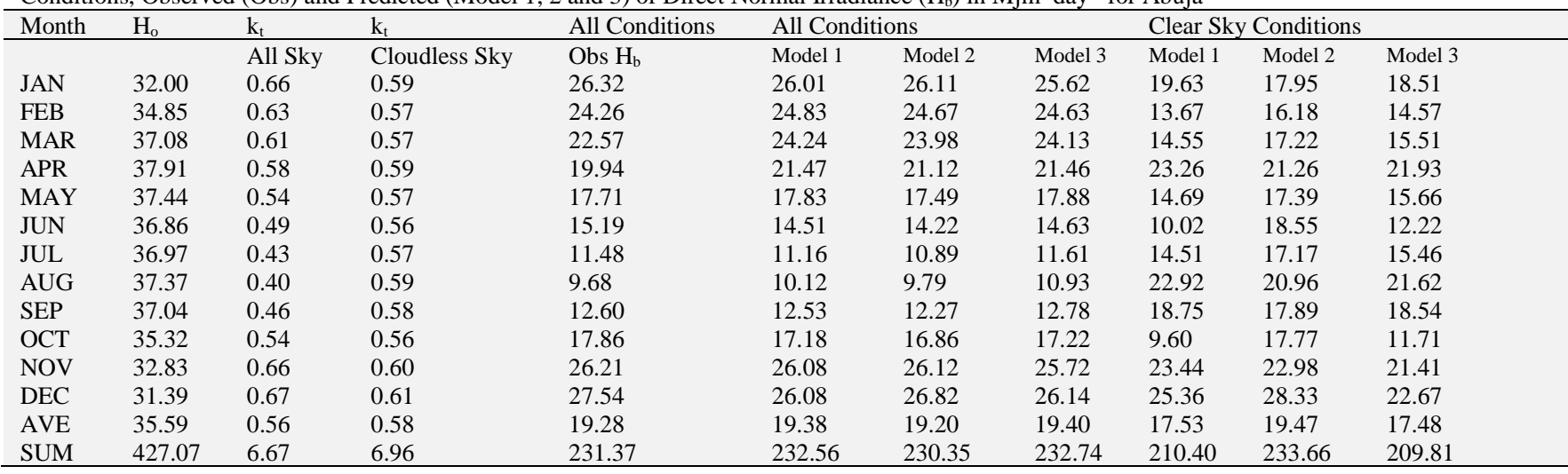

Table 6: Monthly Mean Daily Values of Extraterrestrial Solar Radiation $\left(\mathrm{H}_{\mathrm{o}}\right)$ in $\mathrm{Mjm}^{-2} \mathrm{day}^{-1}$, Clearness Index $\left(\mathrm{k}_{\mathrm{t}}\right)$ Under All Sky Conditions and Clear Sky

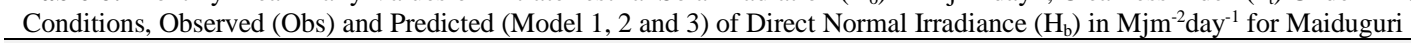

\begin{tabular}{|c|c|c|c|c|c|c|c|c|c|c|}
\hline \multirow[t]{2}{*}{ Month } & \multirow[t]{2}{*}{$\mathrm{H}_{\mathrm{o}}$} & \multirow{2}{*}{$\begin{array}{l}\mathrm{k}_{\mathrm{t}} \\
\text { All Sky }\end{array}$} & \multirow{2}{*}{$\begin{array}{l}\mathrm{k}_{\mathrm{t}} \\
\text { Cloudless Sky }\end{array}$} & \multirow{2}{*}{$\begin{array}{l}\text { All Conditions } \\
\mathrm{Obs} \mathrm{H}_{\mathrm{b}}\end{array}$} & \multicolumn{3}{|c|}{ All Conditions } & \multicolumn{3}{|c|}{ Clear Sky Conditions } \\
\hline & & & & & Model 1 & Model 2 & Model 3 & Model 1 & Model 2 & Model 3 \\
\hline JAN & 31.39 & 0.64 & 0.59 & 25.56 & 23.59 & 23.56 & 23.53 & 23.19 & 23.26 & 23.22 \\
\hline FEB & 34.16 & 0.66 & 0.60 & 27.04 & 27.89 & 27.90 & 27.37 & 26.97 & 27.13 & 26.93 \\
\hline APR & 38.02 & 0.63 & 0.60 & 23.76 & 26.69 & 26.66 & 26.94 & 27.13 & 27.17 & 27.19 \\
\hline MAY & 37.87 & 0.06 & 0.60 & 23.87 & 24.17 & 24.20 & 24.75 & 24.22 & 24.16 & 24.32 \\
\hline JUN & 37.44 & 0.57 & 0.59 & 20.47 & 20.88 & 21.06 & 21.67 & 21.22 & 21.11 & 21.29 \\
\hline JUL & 37.48 & 0.52 & 0.58 & 16.78 & 16.40 & 16.93 & 16.98 & 16.81 & 16.72 & 16.71 \\
\hline AUG & 37.62 & 0.49 & 0.57 & 14.51 & 14.27 & 15.02 & 14.43 & 14.27 & 14.25 & 13.99 \\
\hline SEP & 36.90 & 0.54 & 0.57 & 17.82 & 17.89 & 18.26 & 18.63 & 18.28 & 18.17 & 18.27 \\
\hline OCT & 34.78 & 0.61 & 0.59 & 22.68 & 22.70 & 22.71 & 23.17 & 23.10 & 23.06 & 23.18 \\
\hline $\mathrm{NOV}$ & 31.97 & 0.66 & 0.61 & 26.42 & 25.46 & 25.45 & 25.11 & 25.23 & 25.39 & 25.20 \\
\hline DEC & 30.38 & 0.63 & 0.58 & 24.73 & 21.96 & 21.93 & 22.06 & 21.69 & 21.72 & 21.73 \\
\hline AVE & 35.40 & 0.60 & 0.59 & 22.49 & 22.49 & 22.73 & 22.78 & 22.60 & 22.61 & 22.59 \\
\hline SUM & 424.80 & 7.23 & 7.09 & 269.86 & 270.96 & 272.73 & 273.35 & 271.15 & 271.38 & 271.92 \\
\hline
\end{tabular}

Table 7: Monthly Mean Daily Values of Extraterrestrial Solar Radiation $\left(\mathrm{H}_{\mathrm{o}}\right)$ in $\mathrm{Mjm}^{-2} \mathrm{day}^{-1}$, Clearness Index $\left(\mathrm{k}_{\mathrm{t}}\right)$ Under All Sky Conditions and Clear Sky Conditions, Observed (Obs) and Predicted (Model 1, 2 and 3) of Direct Normal Irradiance $\left(\mathrm{H}_{\mathrm{b}}\right)$ in Mjm $\mathrm{May}^{-1}$ for Sokoto $^{-2}$

\begin{tabular}{|c|c|c|c|c|c|c|c|c|c|c|}
\hline \multirow[t]{2}{*}{ Month } & \multirow[t]{2}{*}{$\mathrm{H}_{\mathrm{o}}$} & \multirow{2}{*}{$\begin{array}{l}\mathrm{k}_{\mathrm{t}} \\
\text { All Sky }\end{array}$} & \multirow{2}{*}{$\begin{array}{l}\mathrm{k}_{\mathrm{t}} \\
\text { Cloudless Sky }\end{array}$} & \multirow{2}{*}{$\begin{array}{l}\text { All Conditions } \\
\mathrm{Obs}_{\mathrm{b}}\end{array}$} & \multicolumn{3}{|c|}{ All Conditions } & \multicolumn{3}{|c|}{ Clear Sky Conditions } \\
\hline & & & & & Model 1 & Model 2 & Model 3 & Model 1 & Model 2 & Model 3 \\
\hline JAN & 30.42 & 0.65 & 0.60 & 25.42 & 22.52 & 22.60 & 22.52 & 20.90 & 21.40 & 20.98 \\
\hline FEB & 33.44 & 0.69 & 0.63 & 28.80 & 28.03 & 27.89 & 27.89 & 24.79 & 24.92 & 24.72 \\
\hline APR & 38.09 & 0.68 & 0.64 & 27.61 & 30.73 & 30.65 & 30.62 & 28.87 & 28.54 & 28.77 \\
\hline MAY & 38.30 & 0.66 & 0.63 & 26.86 & 29.57 & 29.59 & 29.53 & 28.39 & 28.54 & 28.32 \\
\hline JUN & 38.02 & 0.65 & 0.64 & 26.64 & 28.78 & 28.84 & 28.76 & 28.81 & 28.49 & 28.72 \\
\hline JUL & 37.94 & 0.59 & 0.62 & 21.85 & 22.91 & 23.37 & 23.07 & 27.49 & 27.92 & 27.43 \\
\hline AUG & 37.84 & 0.55 & 0.60 & 17.93 & 17.63 & 18.56 & 17.77 & 26.10 & 26.61 & 26.10 \\
\hline SEP & 36.72 & 0.59 & 0.59 & 20.92 & 21.70 & 22.19 & 21.86 & 24.69 & 24.99 & 24.71 \\
\hline OCT & 34.16 & 0.64 & 0.60 & 24.34 & 24.29 & 24.45 & 24.34 & 23.57 & 24.03 & 23.57 \\
\hline NOV & 31.07 & 0.67 & 0.62 & 27.07 & 24.72 & 24.68 & 24.65 & 22.50 & 22.86 & 22.46 \\
\hline DEC & 29.34 & 0.64 & 0.60 & 25.02 & 21.49 & 21.58 & 21.51 & 20.24 & 20.64 & 20.24 \\
\hline AVE & 35.15 & 0.64 & 0.62 & 25.04 & 25.17 & 25.33 & 25.57 & 25.34 & 25.52 & 25.30 \\
\hline SUM & 421.78 & 7.69 & 7.41 & 300.42 & 302.02 & 303.96 & 302.03 & 304.07 & 306.21 & 303.54 \\
\hline
\end{tabular}




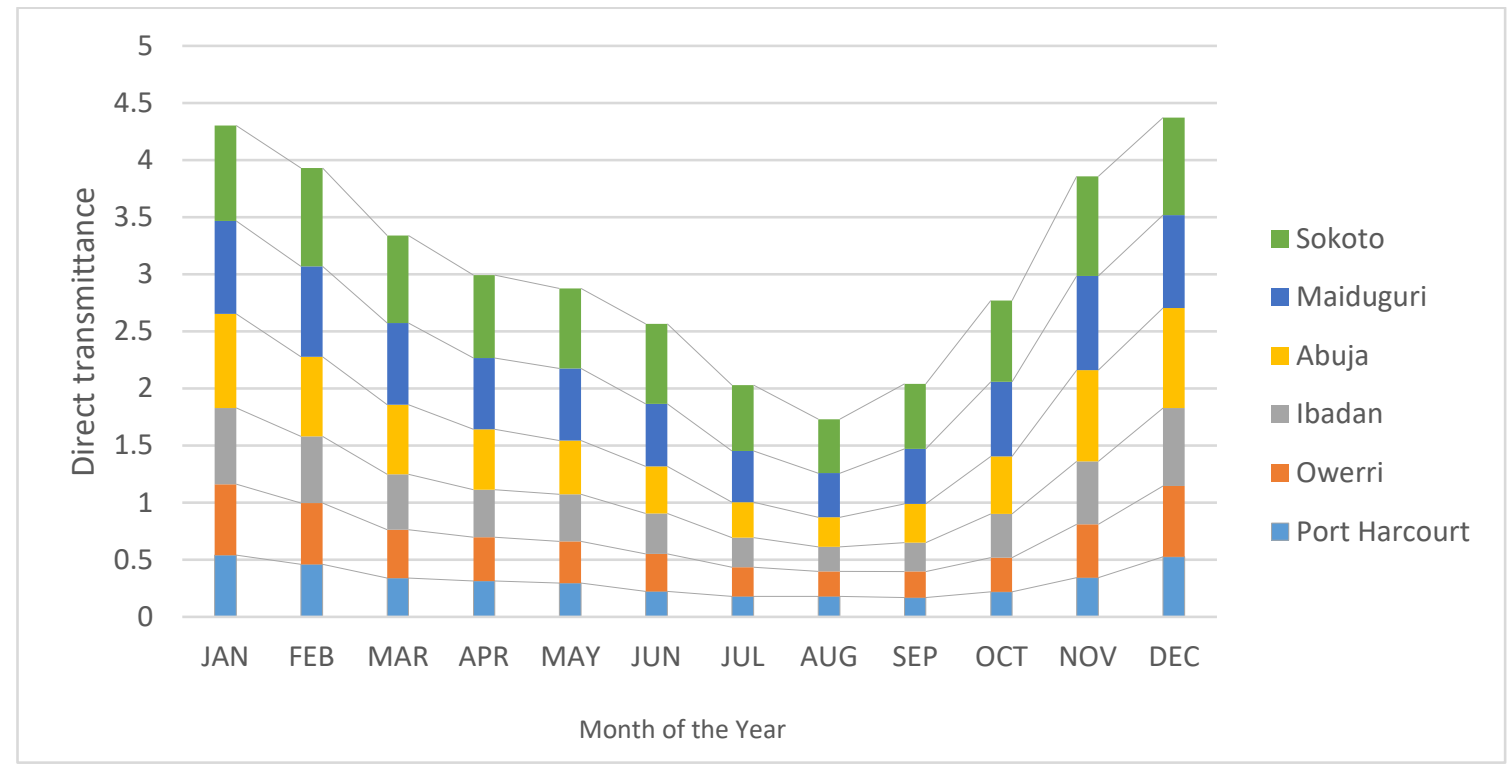

Fig. 2: Variation of Direct Transmittance for Studied Meteorological Stations.

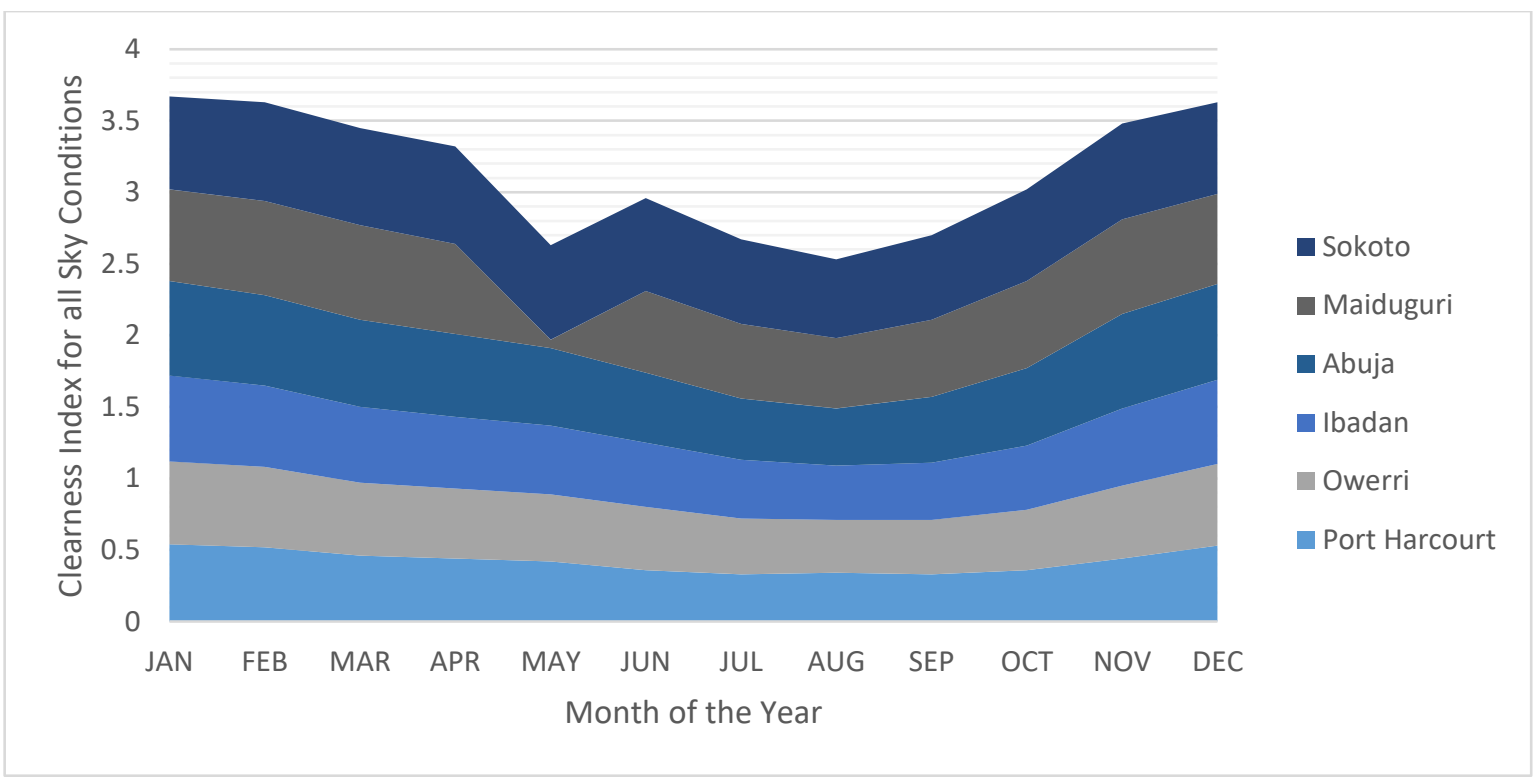

Fig. 3: Variation of Clearness Index under All Sky Conditions for Studied Meteorological Stations.

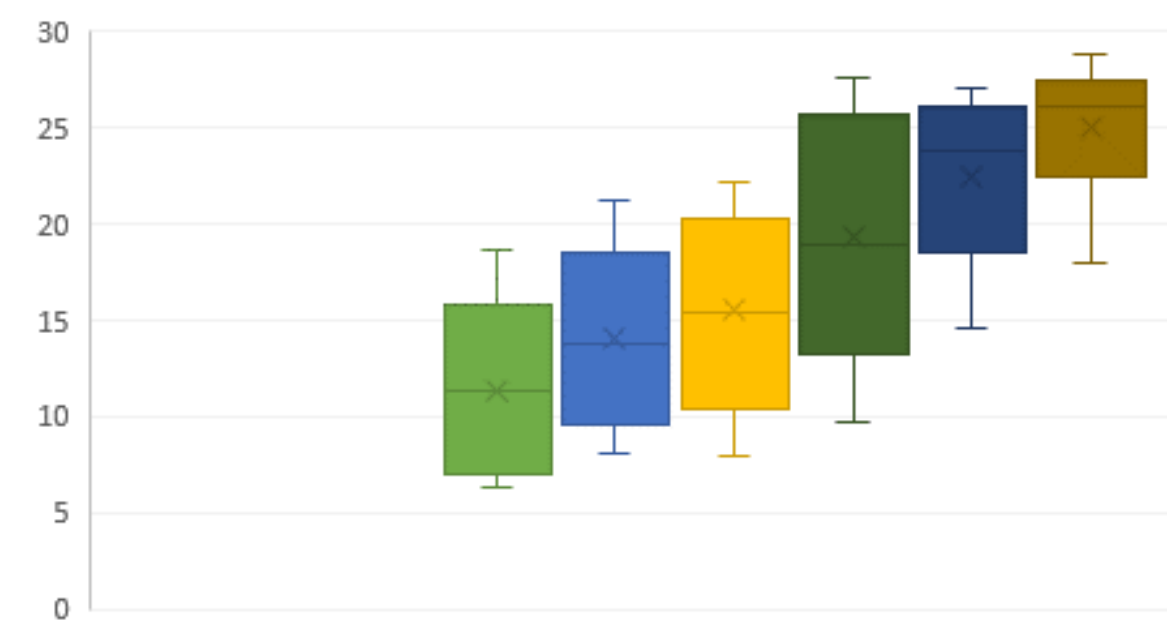

Port Harcourt $\square$ Owerri $\square$ Ibadan $\square$ Abuja $\square$ Maiduguri $\square$ Sokoto

Fig. 4: Boxplot Diagram of the Variation of Direct Normal Irradiance for the Studied Meteorological Stations. 


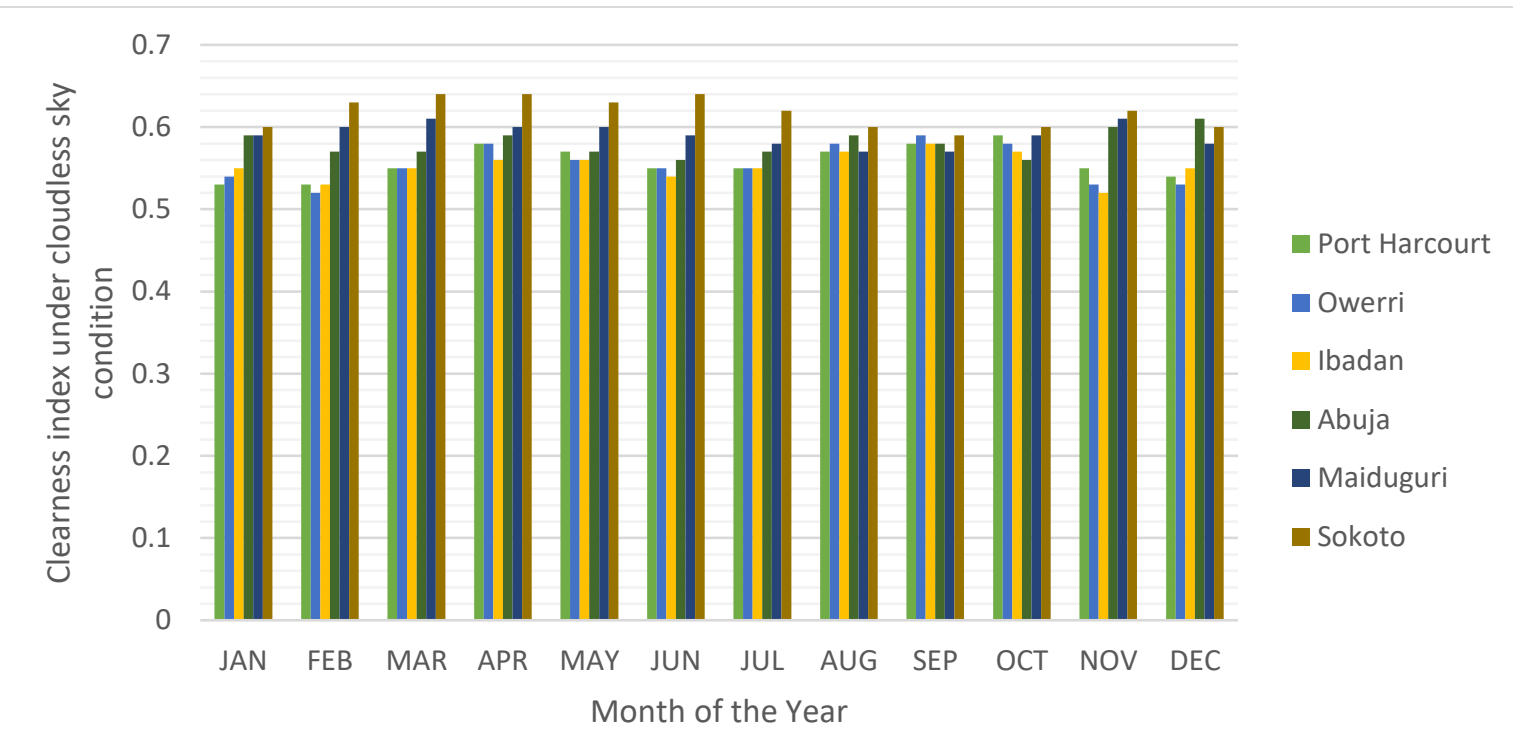

Fig. 5: Variation of Clearness Index under Cloudless Sky Conditions for the Studied Meteorological Stations.

Table 8: Statistical Results for the Validation of the of Predicted (Model) Direct Normal Irradiance (DNI) in Terms of their Capability For Estimating The Direct Normal Irradiance Under Various Sky Conditions for Port Harcourt, Owerri, Ibadan, Abuja, Maiduguri and Sokoto

\begin{tabular}{|c|c|c|c|c|c|c|}
\hline Stations & Models & $\begin{array}{l}\text { Sky } \\
\text { Conditions }\end{array}$ & $b_{o}$ & $\mathrm{~b}_{1}$ & $\mathrm{~b}_{2}$ & $\mathrm{R}^{2}$ \\
\hline Port Harcourt & 3 & $\begin{array}{l}\text { All Sky } \\
\text { Clear Sky } \\
\text { All Sky } \\
\text { Clear sky } \\
\text { All Sky } \\
\text { Clear sky }\end{array}$ & $\begin{array}{l}0.289 \\
38.396 \\
-1.572 \\
17.208 \\
-2.424 \\
-110.927\end{array}$ & $\begin{array}{l}-1.367 \\
-132.552 \\
-0.616 \\
-72.460 \\
4.186 \\
124.351\end{array}$ & $\begin{array}{l}3.361 \\
115.063 \\
2.362 \\
80.321 \\
-164.970 \\
-164.970\end{array}$ & $\begin{array}{l}0.942 \\
0.559 \\
0.941 \\
0.559 \\
0.559 \\
0.559\end{array}$ \\
\hline Owerri & 3 & $\begin{array}{l}\text { All Sky } \\
\text { Clear Sky } \\
\text { All Sky } \\
\text { Clear sky } \\
\text { All Sky } \\
\text { Clear sky }\end{array}$ & $\begin{array}{l}0.410 \\
14.140 \\
-1.622 \\
9.278 \\
-3.578 \\
31.350\end{array}$ & $\begin{array}{l}-2.005 \\
-44.771 \\
-0.778 \\
-26.204 \\
5.592 \\
34.210\end{array}$ & $\begin{array}{l}4.075 \\
35.990 \\
2.593 \\
27.005 \\
-4.021 \\
-49.831\end{array}$ & $\begin{array}{l}0.984 \\
0.604 \\
0.985 \\
0.604 \\
0.983 \\
0.603\end{array}$ \\
\hline Abuja & 3 & $\begin{array}{l}\text { All Sky } \\
\text { Clear Sky } \\
\text { All Sky } \\
\text { Clear sky } \\
\text { All Sky } \\
\text { Clear sky }\end{array}$ & $\begin{array}{l}0.614 \\
-17.142 \\
-1.385 \\
38.710 \\
-4.810 \\
18.262\end{array}$ & $\begin{array}{l}-2.652 \\
49.800 \\
-1.024 \\
-171.933 \\
6.881 \\
-17.000\end{array}$ & $\begin{array}{l}4.464 \\
-33.400 \\
2.702 \\
192.051 \\
-5.901 \\
33.400\end{array}$ & $\begin{array}{l}0.987 \\
0.311 \\
0.990 \\
0.382 \\
0.958 \\
0.437\end{array}$ \\
\hline Maiduguri & 3 & $\begin{array}{l}\text { All Sky } \\
\text { Clear Sky } \\
\text { All Sky } \\
\text { Clear sky } \\
\text { All Sky } \\
\text { Clear sky }\end{array}$ & $\begin{array}{l}0.475 \\
-0.553 \\
-1.295 \\
-1.831 \\
-1.414 \\
-0.699\end{array}$ & $\begin{array}{l}-2.222 \\
1.525 \\
0.848 \\
1.237 \\
3.099 \\
2.305\end{array}$ & $\begin{array}{l}4.122 \\
0.771 \\
2.419 \\
0.150 \\
-0.0887 \\
0.189\end{array}$ & $\begin{array}{l}0.896 \\
0.881 \\
0.895 \\
0.885 \\
0.881 \\
0.880\end{array}$ \\
\hline Sokoto & 3 & $\begin{array}{l}\text { All Sky } \\
\text { Clear Sky } \\
\text { All Sky } \\
\text { Clear sky } \\
\text { All Sky } \\
\text { Clear sky }\end{array}$ & $\begin{array}{l}-1.949 \\
-0.737 \\
-2.406 \\
-5.488 \\
2.788 \\
0.552\end{array}$ & $\begin{array}{l}5.897 \\
3.013 \\
3.240 \\
14.697 \\
-1.503 \\
0.717\end{array}$ & $\begin{array}{l}-2.692 \\
-1.058 \\
-2.000 \\
-14.361 \\
5.690 \\
1.318\end{array}$ & $\begin{array}{l}0.719 \\
0.061 \\
0.719 \\
0.143 \\
0.737 \\
0.061\end{array}$ \\
\hline
\end{tabular}


Table 9: Statistical Results for the Validation of the Predictive Models of Direct Normal Irradiance in Terms of Their Capability for Estimating Direct Normal Irradiance for Port Harcourt, Owerri, Ibadan, Abuja, Maiduguri and Sokoto.

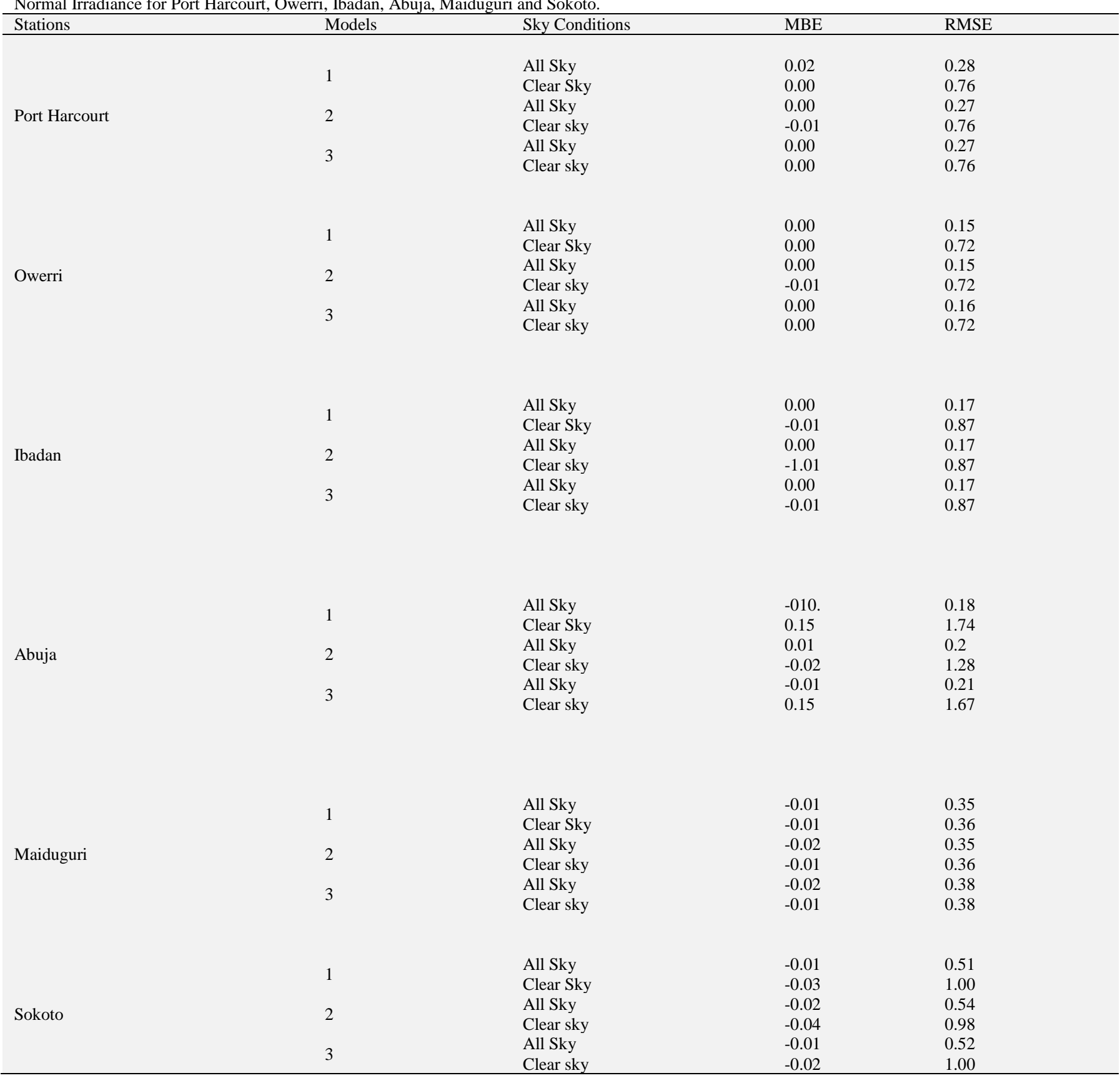



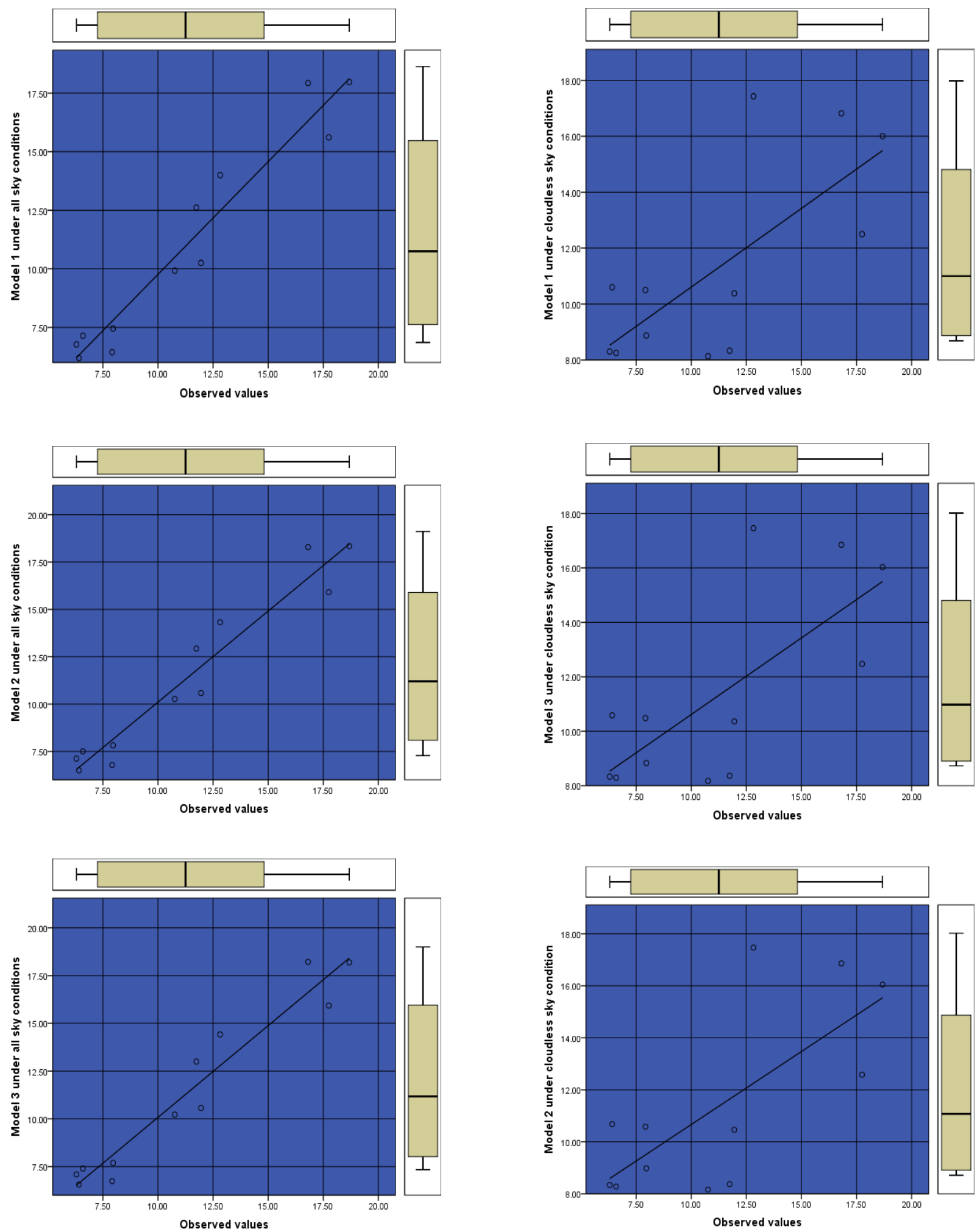

Fig. 6: Scatter Plots and Box diagrams between observed and predicted (models) direct normal irradiance under all sky condition (model 1,2,3) and under cloudless sky condition (model 1,2,3) for Port Harcourt 

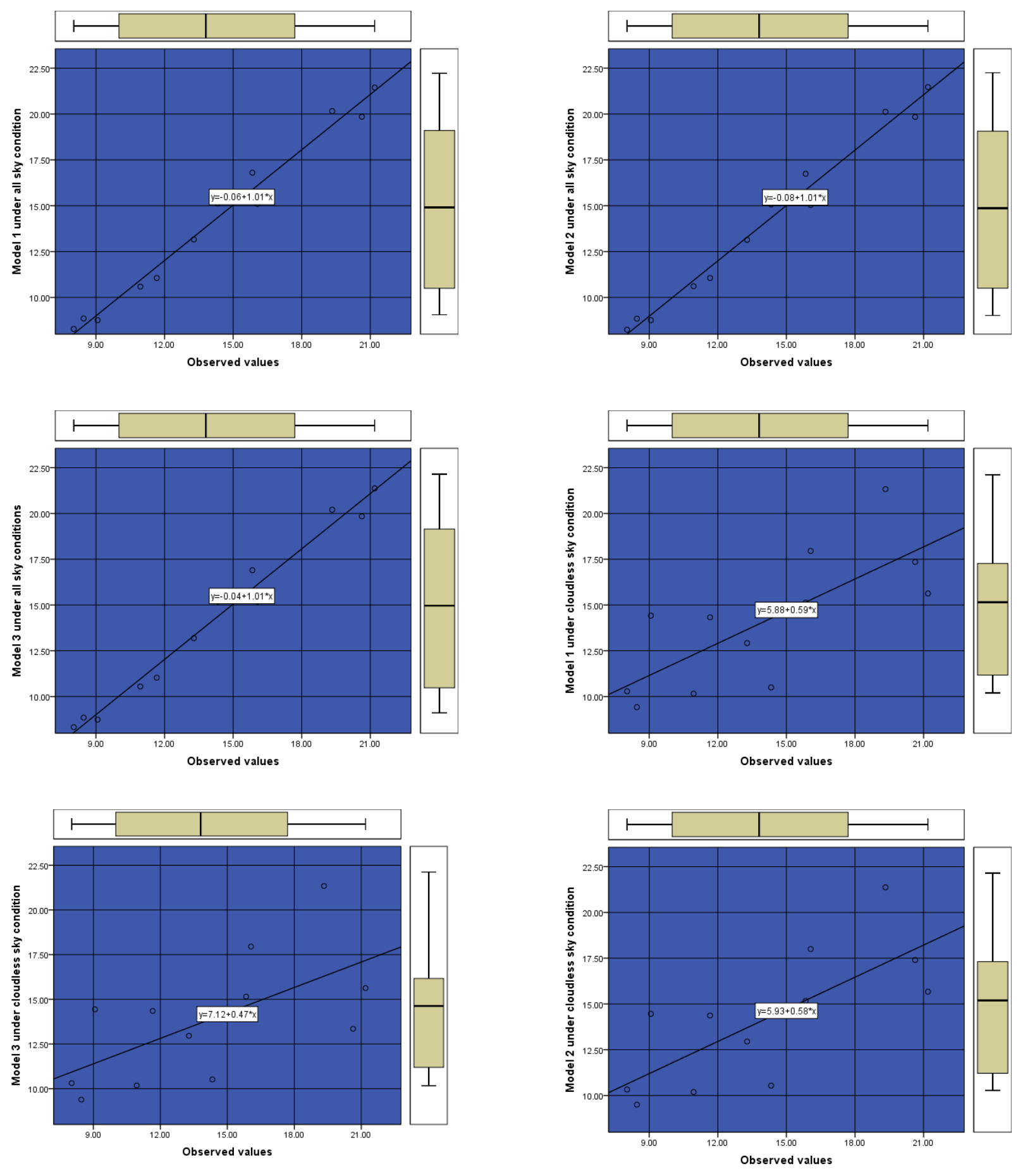

Fig. 7: Scatter Plots and Box diagrams between observed and predicted (models) direct normal irradiance under all sky condition (model 1,2,3) and under cloudless sky condition (model 1,2,3) for Owerri 

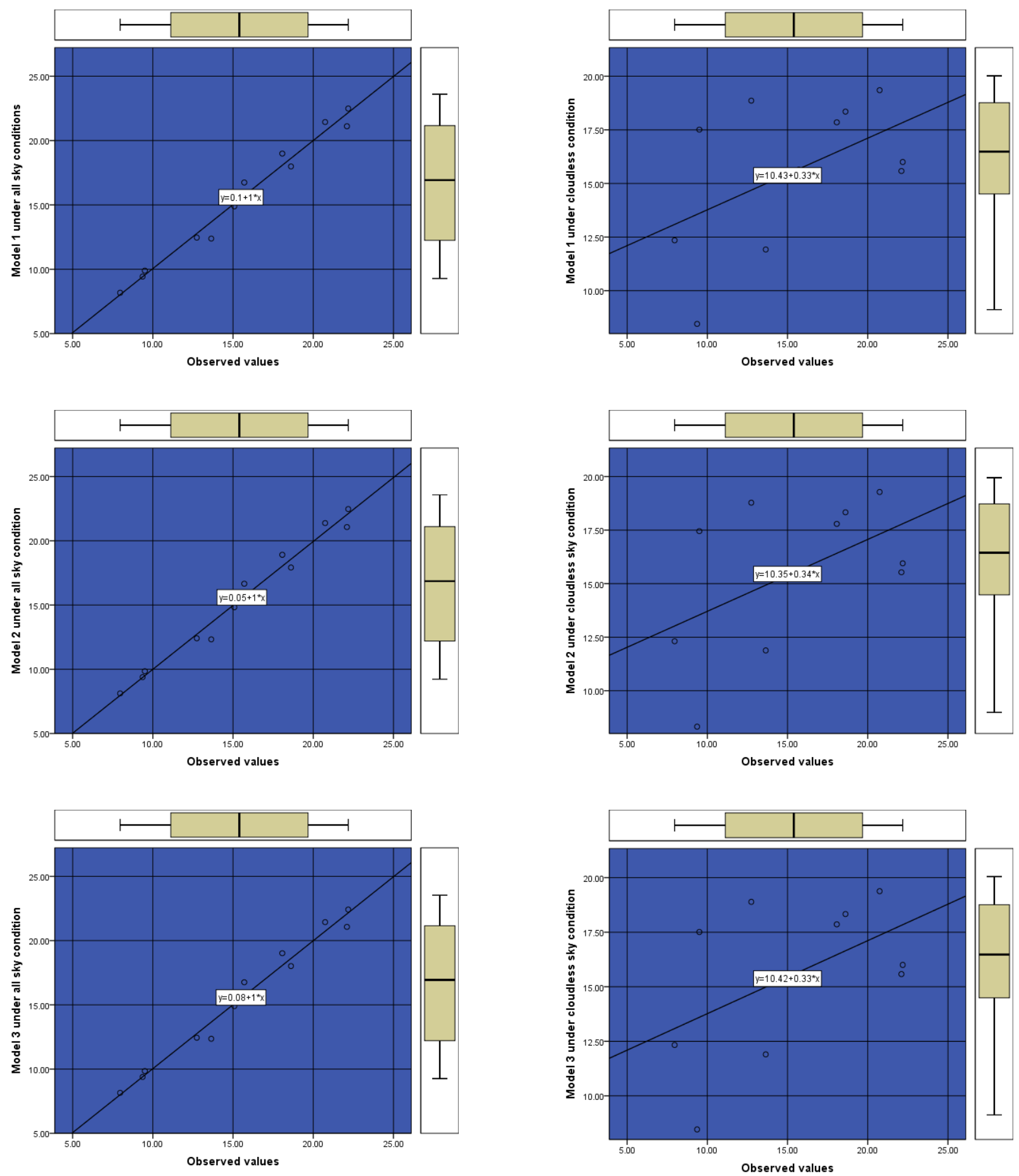

Fig. 8: Scatter Plots and Box diagrams between observed and predicted (models) direct normal irradiance under all sky condition (model 1,2,3) and under cloudless sky condition (model 1,2,3) for Ibadan 

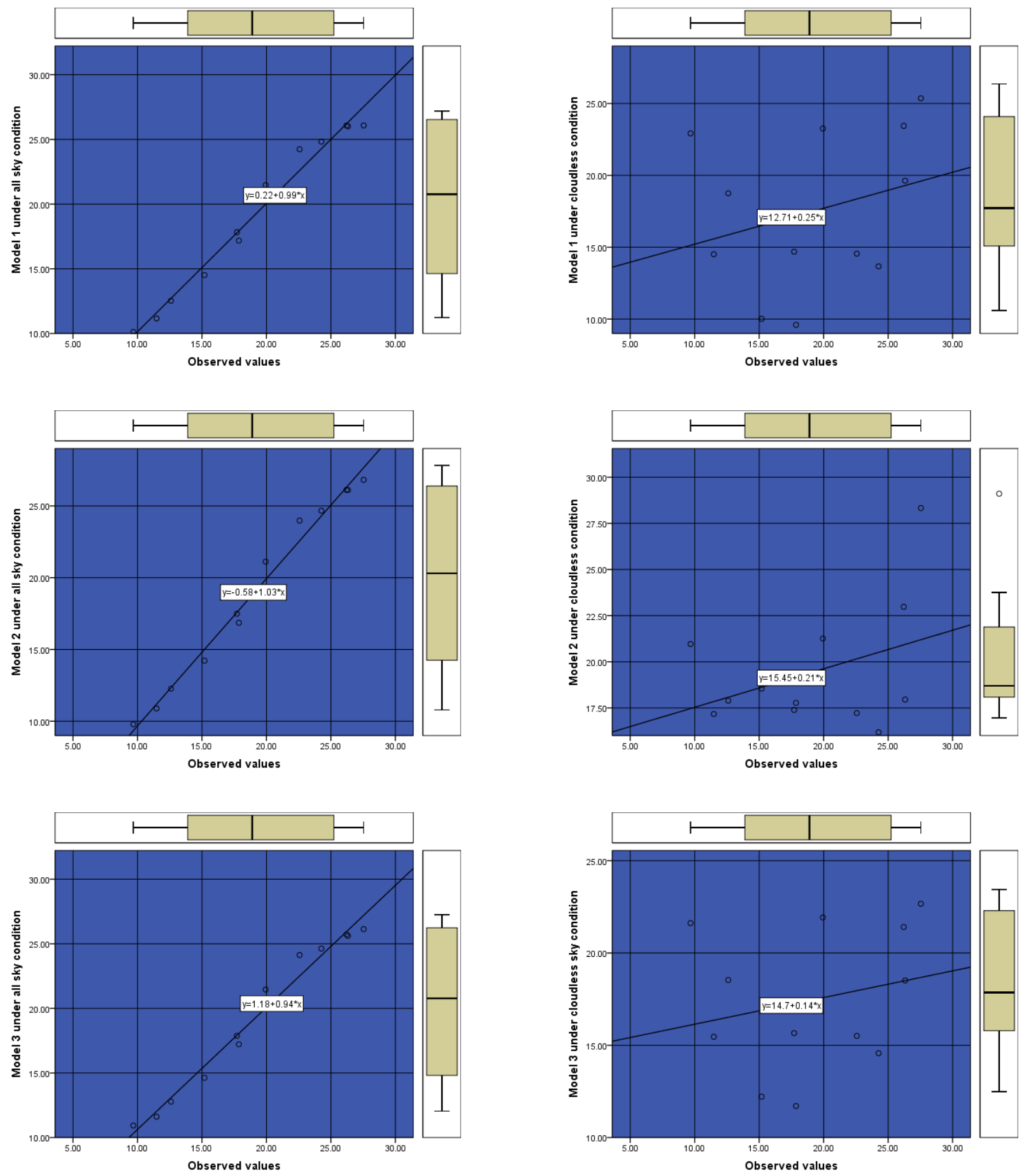

Fig. 9: Scatter Plots and Box diagrams between observed and predicted (models) direct normal irradiance under all sky condition (model 1,2,3) and under cloudless sky condition (model 1,2,3) for Abuja 

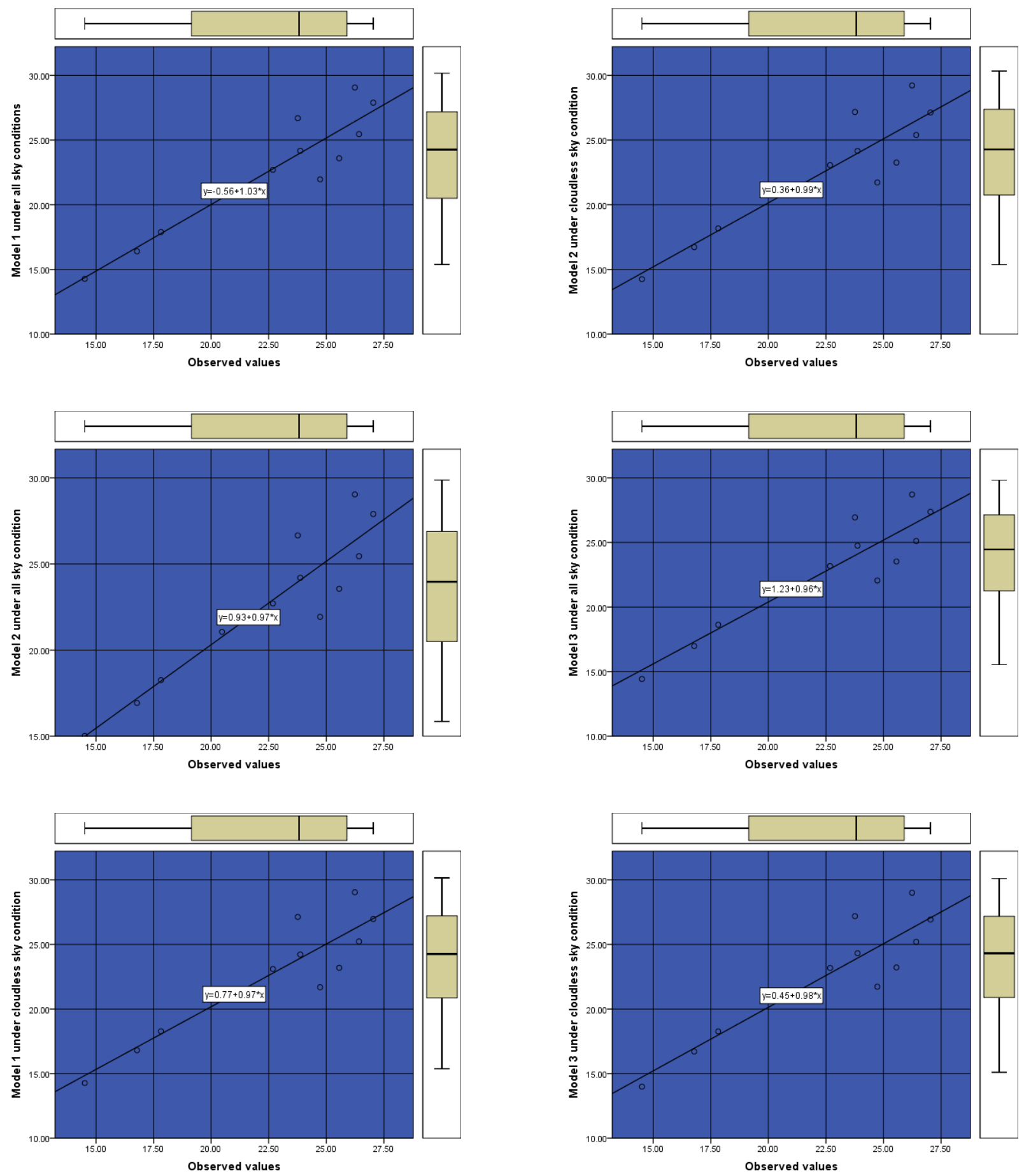

Fig. 10: Scatter Plots and Box diagrams between observed and predicted (models) direct normal irradiance under all sky condition (model 1,2,3) and under cloudless sky condition (model 1,2,3) for Maiduguri 

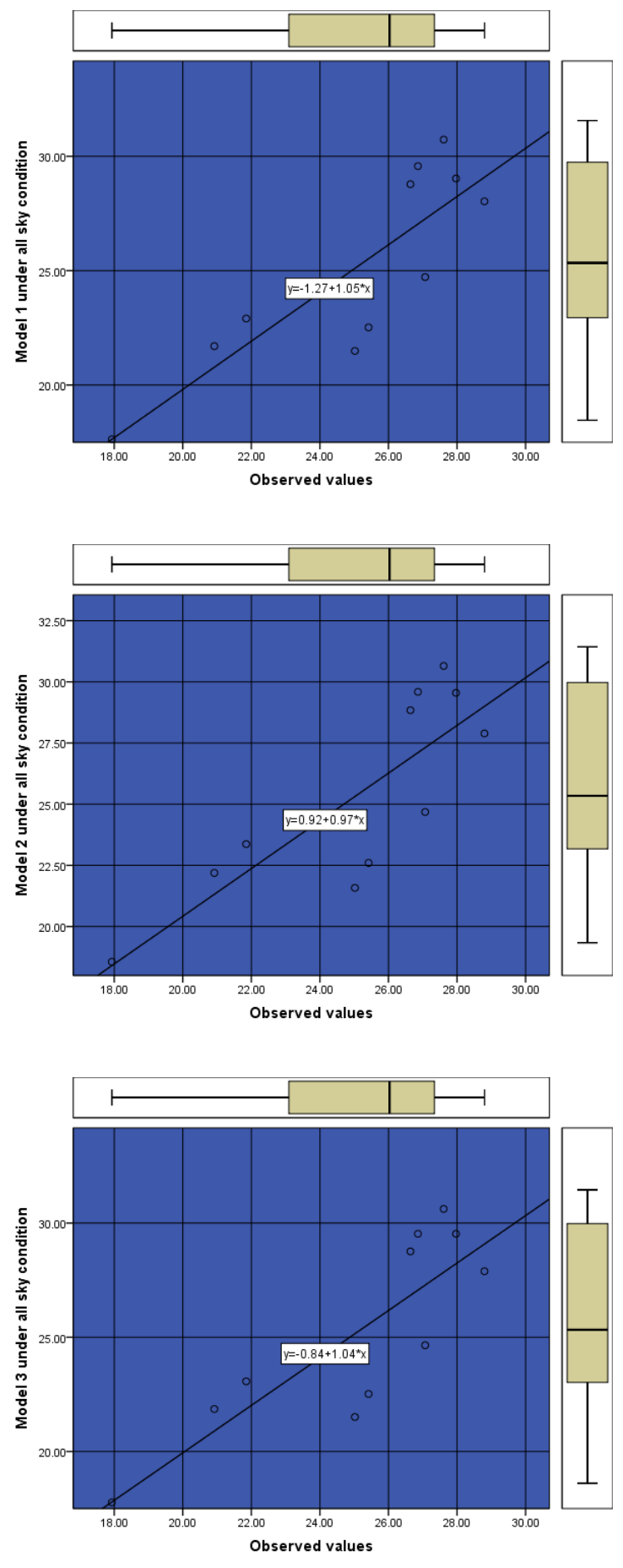
of direct transmittance, as expected from the outputs of decomposition type model and in a tropical site. This trend was observed in Lagos (tropical rain forest) by Maduekwe and Chendo [10, 15]. It was also observed that $\mathrm{H}_{\mathrm{b}}$ increases with latitude from Lat 4.4 13. $03^{\circ} \mathrm{N}$ along the tropical ecological zones from the far southern tropical ecological zone of mangrove swamp (FSZMS) of Port Harcourt to the far Northern tropical zone of Sahel Savannah (FNZSS) of Sokoto as expected for a tropical site. The same trend was observed by Battles et al. [20] at six stations in Spain. This variation was mainly due to the trends in cloudiness and associated atmospheric moisture with the movement through the Hadley cell circulation system along the equatorial line.

The Nigeria weather condition is classified into two seasons: Dry and wet season. Dry reason is attributed to the influence of inter tropical convergence zone (ITCZ) producing tropical Continental (TC) associated with dry and dusty North - East winds (eateries) which blows from the Sahara Desert and finally prevail over Nigeria; thus producing the dry-season conditions. The implication is that there is a prolonged dry season in the far North, while the far south undergoes short dry periods annually.

With the movement of the ITCZ into the Northern hemisphere, the rain-bearing south westerlies prevail as far inland as possible to bring rainfall during the rainy season. This results to prolonged rainy season in the far South while the far North undergoes short rainy periods annually.

The dry season is from November to March while the wet season starts in April and ends in October. The rainy season is characterized by overcast and heavy rain clouds. This gives rise to the relatively high $\mathrm{Hb}_{\mathrm{b}}$ and low clearness index as observed between the months of May-October compared to the dry-season months for all sky condition. The same trend was observed by Maduekwe and Chendo [10,15] in Lagos, Nigeria while the clearness index was relatively high under clear sky weather shown in Fig. 5.

The lowest $\mathrm{H}_{\mathrm{b}}$ of $6.30 \mathrm{MJm}^{-2} \mathrm{day}^{-1}$ occurred during the months of September for Port Harcourt. This report is comparable with the result registered by Maduekwe and Chendo [10, 15] in Lagos, Sothern Nigeria. While the minimum clearness index of 0.333 was recorded during the months of July and September for Port Harcourt under all sky conditions compared to higher value of 0.52 recorded in the month of February for Owerri in the same tropical zone under clear sky conditions as expected for tropical site. This value is in agreement with the report in Southern Nigeria [23-30] This is due to the presence of relatively higher cloud cover, relative humidity, prolonged rainy season and more absorption of diffuse solar radiation and near infrared radiation (NIR) in the solar spectrum thereby producing low magnitude of $\mathrm{Hb}$ received in the zone.

The maximum values of $\mathrm{Hb}$ of $28.80 \mathrm{MJm}^{-2} \mathrm{day}^{-1}$ was recorded in February for Sokoto. While the highest clearness index for all sky conditions is 0.69 recorded during February for Sokoto. However, Sokoto registered the highest value of 0.64 clearness index in the months of March, April and June under clear sky conditions. This could be attributed to the presence of low smog, relative humidity, cloud cover, low absorption of diffuse solar radiation and NIR and prolonged dry season with associated highest latitude $\left(13.067^{\circ} \mathrm{N}\right)$ over Sokoto and its environs thereby enhancing $\mathrm{H}_{\mathrm{b}}$ and clearness index received at the site. This trend was comparable to the observation of Sambo [31] for clearness index in Northern Nigeria.

\subsubsection{Classification of clearness index under all sky conditions}

The monthly mean clearness index designates the percentage depletion by the sky of the incoming $\mathrm{H}$ and therefore indicates, both the level of availability of solar radiation and changes in the atmospheric condition in a given locality [32-33]. The prevailing clearness index varied between the range of $0.33-0.50$ and $0.43-$ 0.68 between the months of April to October in the rainy season and $0.44-0.60$ and $0.61-0.69$ between the months of November to March in the dry Season with an annual range of $0.42-0.64$ from the FSZMS of Port Harcourt to the FNZSS of Sokoto. These results fall within the report of several researchers in Nigeria literature [23-31].

Using the weather classification proposed by Iqbal [7] which are: (1) heavily overcast weather ( $\mathrm{kt} \leq 0.4)$; (2) partly overcast weather $(0.6 \leq \mathrm{kt} \leq 0.4)$; and (3) clear weather $(\mathrm{kt} \geq 7)$. The prevailing weather conditions of the southern ecological zones located at latitude 4.75 and $6.583{ }^{\circ} \mathrm{N}$ along the mangrove and tropical rainforest of Port Harcourt, Owerri and Ibadan are partly overcast weather except between the months of June to October for Port Harcourt; July to September for Owerri; and August for Ibadan when it falls within the heavily overcast weather as shown in Figure 3. These indicate that the remarkable feature of the southern tropical zones is dominance of heavily overcast weather. It was observed that $\mathrm{Hb}$ component of the $\mathrm{H}$ increases temporarily with an increase in the clearness index at all sky condition and then increases rapidly as the heavily overcast weather become clearer. This reveals that $\mathrm{H}_{b}$ is optimally controlled by clearness index under all sky conditions in the Southern Nigeria. These results agreed favorably with the report in Southern Nigeria [23-31].

The weather conditions of the Northern tropical zones located between the latitude 9.067 and $13.067{ }^{\circ} \mathrm{N}$ along the Guinea savannah to Sahel savannah zones of Abuja, Maiduguri and Sokoto are partly overcast weather throughout the year. This also could be due to the presence of low relative humidity, smog, cloud cover, low absorption of NIR, diffuse solar radiation and prevailing prolonged dry season in the zones. Thus, a remarkable feature of the Northern tropical zones is the dominance of partly overcast weather under all sky conditions. The level of availability of clearness index for all sky condition in this research compared favourably to the report of Sambo [31] in Northern Nigeria.

\subsubsection{Fitting under various sky conditions}

The following observations were deduced from the analyses of the result presented in Table $2-7$. This is similar to the result recorded by Maduekwe and Chendo [10] for all sky condition and Gueymard [5-6] under clear sky conditions. From Table 2-7, it can be observed that the total annual $\mathrm{Hb}_{\mathrm{b}}$ for Port Harcourt, Owerri, Ibadan and Abuja, Maiduguri and Sokoto are $135.68 \mathrm{MJm}^{-2} \mathrm{day}^{-1}$, 169.17 $\mathrm{MJm}^{-2} \mathrm{day}^{-1}, \quad 185.96 \mathrm{MJm}^{-2} \mathrm{day}^{-1}, 232.56 \mathrm{MJm}^{-2} \mathrm{day}^{-1}$, 269.86 $\mathrm{MJm}^{-2} \mathrm{day}^{-1}$ and 300. $42 \mathrm{MJm}^{-2} \mathrm{day}^{-1}$ respectively. The radiation obtained throughout the year is high for all the six tropical ecological zones. This indicates that concentrating solar thermal installations and installations that track the position of the sun such as Concentrating Solar Power (CSP) systems, parabolic tough, linear-freshed or solar tower, high-intensity solar cells and high-temperature heat engines, renewable power plants, heating, natural lighting and production of solar-energy systems have the high potential for $\mathrm{H}_{\mathrm{b}}$ utilization at any time of the months as the fluxes are generally greater than $10 \mathrm{MJm}^{-2} \mathrm{day}^{-1}$ except in the months of June to October for Port Harcourt, July to September for Owerri and Ibadan respectively in the Southern ecological zones. Hence, solar systems can utilize $\mathrm{H}_{\mathrm{b}}$ at any time of the year provided other conditions are favourable except probably in the above mentioned months in the Southern ecological zones.

The coefficients fitted with monthly averages for the six sites, using the quadratic and the proposed linear logarithmic and quadratic exponential proposed models are shown in Table 8 . The coefficients of the three (3) models in all the sites, fitted with monthly data are significant up to 5\% for clear sky and all sky conditions. They change from place to place with the largest differences being observed for Sokoto under all sky conditions and for all sites under clear sky condition for the three models. This changes depend on the local climatic conditions for all sky conditions while variation for clear sky condition depends on the local climate conditions with low values of $\mathrm{H}_{\mathrm{b}}$ under all sky condition correlated with high values of clearness index under clear sky conditions. The coefficient of bo changed in the internal $-1.949<\mathrm{b}_{0}<0.614$, 
$2.406<\mathrm{b}_{0}<-1.295,-4.810<\mathrm{b}_{0}<-1.414 ; \mathrm{b}_{1}$ in the internal $-2.652<$ $\mathrm{b}_{1}<5.897,-1.024<\mathrm{b}_{1}<3.240,-1.503<\mathrm{b}_{1}<5.592 ; \mathrm{b}_{2}$ in the internal $2.692<b_{2}<4.464,-2.000<b_{2}<2.702,-4.021<b_{2}<5.690$ for all sky conditions. These coefficients are different from $0.208<\mathrm{b}<$ 2.16 obtained by Maduekwe and Chendo $[10,15]$ at Lagos, Nigeria using a short term data from two years $(1990-1991)$ obtained from global and diffuse solar irradiance incident on a horizontal surface within (Lat $6.58^{\circ} \mathrm{N}$, Long $3.33^{\circ} \mathrm{E}$ ) employing monthly mean daily values with quadratic model of direct transmittance and clearness index relations. This variation could be attributed to the short-term data $(1990$ - 1991) used as short data increase error in estimation and local climatic changes from 1990 - 1991 compared to $1983-2005$ employed in this study.

Similar weather variation and climate local conditions range of 0.941 - 0.990 were observed for Port Harcourt, Owerri, Ibadan and Abuja along mangrove swamp of Port Harcourt to Guinea Savannah of Abuja as shown in Table 8. This reveals that direct transmittance is optimally controlled by clearness index from FSZMS of Port Harcourt to North-Central Zone of Guinea Savannah (NCZGS) of Abuja in spite of the low correlation obtained under clear sky conditions. That is, $94.1-99.0 \%$ of the clearness index can be accounted using direct transmittance while $1-5.9 \%$ are accounted by other independent atmospheric and meteorological variables that influence direct transmittance such as relative humidity, cloud cover, precipitation because of the presence of prolonged rainfall, heavy smog, short period of dry season, high absorption of $\mathrm{H}_{\mathrm{b}}$ and NIR in the solar spectrum to mention but few that are highly prevalent in these zones with their associated independent atmospheric variables not fitted in the three models under all sky conditions. This range is similar to 0.991 recorded by Maduekwe and Chendo $[10,15]$ in Lagos, South-West Zone of Tropical Rainforest (SWZTR), Nigeria.

Comparable local climate conditions range of $0.719-0.896$ were registered for Sokoto and Maiduguri along North-East Zone of Sudan Savannah (NEZSS) of Maiduguri to North-West Zone of Sahel Savannah (NWZSS) of Sokoto with the corresponding lower values obtained in clear sky conditions. This indicates that direct transmittance is not optimally controlled by clearness index under all sky or clear sky conditions using data employed in this study. That is, $71.9-89.6 \%$ of the clearness index can be accounted for direct transmittance while $10.4-28.1 \%$ are accounted by other independent atmospheric and meteorological variables that influence direct transmittance such as temperature, sunshine duration, ITCZ producing TC associated with dry and dusty North-East winds that are highly prevalent in these zones. This range is lower than the 0.991 recorded by Maduekwe and Chendo [10-15] in SWZTR of Lagos primarily because the local climate conditions.

The maximum correlation of 0.990 was recorded in NCZGS of Abuja using model 2. This could be attributed to the position of Abuja in Nigeria. The controlling local climate conditions in the Southern tropical zones of Port Harcourt, Owerri, and Ibadan and that of two Northern tropical zones of Maiduguri and Sokoto contribute little influence in the NCZG of Abuja. That is, trends in cloudiness and associated atmospheric moisture with the movement of the Hadley cell circulation system along the equatorial line finds a way of balancing the cloudiness in the NCZGS of Abuja. The minimum correlation obtained was 0.719 recorded in the FNZSS of Sokoto using model 1 and 2 as a result of the local climate conditions in the zone.

However, the correlations were generally weaker under clear sky conditions with the range of $0.381-0.604$ in the Southern ecological zones compared Northern ecological zones that revealed appreciable correlation of $0.311-0.885$ except Sokoto in the FNZSS that recorded the weakest correlation between the observed and predicted value of $0.061-0.143$. This variance could be attributed to the estimation of direct transmittance under all sky condition with clearness index under clear sky.

The comparison between the observed and predicted $\mathrm{H}_{\mathrm{b}}$ using the three (3) models under all sky and clear sky conditions are shown in Fig. 6-11 for the six tropical zones. The results indicate a good agreement between the observed and predicted $\mathrm{H}_{\mathrm{b}}$.

\subsubsection{Statistical performance of the models}

The performances of the models are evaluated and compared using statistical parameter such as MBE and RMSE. The summary of the error parameters is presented in Table 9. MBE is a measure of evaluating over estimation and underestimation of the models in the six sites. Positive values of MBE indicate overestimation in predicted values of the $\mathrm{H}_{b}$, while negative values indicate underestimation. From Table 9, it is clear that in the Southern zones, the monthly mean daily $\mathrm{H}_{\mathrm{b}}$ for Port Harcourt and Owerri slightly overestimated all the models except model 2 for clear sky conditions. Ibadan overestimated using all the models under all sky condition and underestimated under clear sky conditions. In the Northern zones, all the models underestimated for Maiduguri and Sokoto under all sky conditions and clear sky conditions. While Abuja was underestimated under all sky conditions using models 1 and 3 and all the models overestimated under clear sky condition except model 2 . This confirms that the proposed models accurately fitted the local climate conditions in three tropical ecological zones of mangrove swamp, Tropical Rain Forest and Guinea Savannah located in Port Harcourt (South-south region), Owerri (South-East), Ibadan (South -West) and Abuja (North-Central). While Maiduguri and Sokoto local climate conditions require more/other atmospheric/metrological parameters to accurately fit in the proposed models. The RMSE test provides information on the short-term performance of the studied model as it allows a term by term comparison of the actual derivation between the predicted and observed values. Table 9 shows that the RMSE for the Southern tropical zones ranged from $0.15-0.28$ under all sky conditions and $0.72-0.87$ under clear sky conditions while the Northern tropical zones ranged from $0.02-0.52$ under all sky conditions and $0.36-1.74$ under all sky conditions. The variation could be attributed to the local climate condition influencing each zone as a result of the trends in cloudiness and associated atmospheric moisture with the movement through the Hadley cell calculation system along the obtained equatorial line. These results fall within 0.04 estimation error observed by Maduekwe and Chendo [10-15] in Lagos. These imply that the regression lines fit the predicted data in the Southern zones while higher values obtained in the Northern zones indicate that the proposed models needed other meteorological parameters to accurately fit the local climate conditions.

\section{Conclusion}

The analysis of the influence of clearness index on $\mathrm{H}_{\mathrm{b}}$ based on the radiation data recorded for Port Harcourt, Owerri, Ibadan, Abuja, Maiduguri and Sokoto representing the six tropical ecological zones in Nigeria was carried out. The annual clearness index implies that the prevailing weather condition in the Southern tropical zones indicates that Port Harcourt, Owerri and Ibadan are heavily overcast while Abuja, Maiduguri and Sokoto experienced partly overcast weather. Higher values of $\mathrm{H}_{b}$ were observed in the FNZSS of Sokoto while lower values were recorded in the FSZMS of Port Harcourt indicating an increasing trend of $\mathrm{H}_{\mathrm{b}}$ from FSZMS to FNZSS, principally caused by the trends in cloudiness and associated atmospheric moisture with the movement of the Hadley cell calculation system along the equatorial line from the FSZMS to FNZSS. Generally, the proposed model suitably predicted stations in the southern tropical zones (Port Harcourt Owerri and Ibadan) and Abuja (NCZGS) and underestimated stations in the North East zone of Sudan Savannah (NEZSS) of Maiduguri and FNZSS of Sokoto. For reasonably reliable estimation, we therefore recommend that the proposed model will function efficiently for any station in mangrove swamp, tropical rainforest and guinea savannah tropical zones in Nigeria. This research paper is the first attempt to qualify $\mathrm{H}_{\mathrm{b}}$ component in the six tropical ecological zones in Nigeria; thus our models can be used to estimate 
$\mathrm{H}_{\mathrm{b}}$ parameters for locations with similar climatological conditions where $\mathrm{H}$ data are readily available.

\section{Acknowledgement}

Our thanks go to the NASA Langley Research Center Atmospheric Science Data Center Surface meteorological and Solar Energy (SSE) web portal supported by the NASA LARC POWER Project for the data used for this research paper. We also wish to thank all the authors cited in this paper for their research works that has made this research possible.

\section{Conflict of interest}

The authors declare that there is no conflict of interest regarding the publication of this paper.

\section{References}

[1] National Aeronautics and Space Administration (NASA) Atmospheric Science data centre, http://econsweb./arc.nasa.gov/sse/.

[2] Bartoli, B., Cuomo, V. Amato, U., Barone, G., Mattanelli, P. (1982) Diffuse and beam components of daily global radiation in Genoa and Macenata. Solar Energy. 28, 307 - 312. https://doi.org/10.1016/0038 092X(82)90304-8.

[3] Benson, R.B., Paris, M.V., Sheny, J.E., Justus, C.G. (1984). Estimation of daily and monthly direct, diffuse and global solar radiation from sunshine duration measurement. solar Energy. 32, 523 - 536 https://doi.org/10.1016/0038-092X(84)90267-6.

[4] Garison, J.D. (1989). A study of the division of global solar irradiance into direct and diffuse irradiance at thirty three U.S sites. Solar Energy. 35, 341-351. https://doi.org/10.1016/0038-092X(85)90142-2.

[5] Gueymard, C. (1993a). Mathematically integrated parameterization of clear-sky beam and global irradiance and its use in daily irradiance applications. Solar Energy. 50, 385 - 397. https://doi.org/10.1016/0038 092X(93)90059-W

[6] Gueymard, C. (1993b). Critical analysis and performance assessment of clear sky solar irradiance models using theoretical and measured data Solar Energy, 51, 121 - 138. https://doi.org/10.1016/0038092X(93)90074-X.

[7] Iqbal, M. (1980). Reduction of hourly diffuse solar radiation from measured hourly global radiation on a horizontal surface. Solar Energy, 23, 491 - 503. https://doi.org/10.1016/0038-092X(80)90317-5.

[23] Akpabio, L.E., Etuk, S.E., (2002). Relationship between solar radiation and sunshine duration for Onne, Nigeria, Turkish Journal of Physics, 27, $161-167$

[24] Augustine, C., Nnabuchi, M.N. (2009). Empirical models for the correlation of global solar radiation with meteorological data for Enugu, $\mathrm{Ni}$ geria - Pacific Journal of Science and Technology, 10, 693 - 700 .

[25] Chineke, T.C. (2008). Equations for estimating global solar radiation in data sparse regions. Renewable Energy. 33, 827 - 837 https://doi.org/10.1016/j.renene.2007.01.018.

[26] Dike, V.N., Chineke, T.C., Nwofor, O.K., Okoro, U.K. (2011). Evaluation of horizontal surface solar radiation levels in Southern Nigeria Journal of Reviewable and sustainable energy. 3, 93-101.

[27] Fagbenle, R.O. (1992). A comparative study of some simple models for global solar in radiation in Ibadan, Nigeria. International Journal of Energy Research. 16, 583 - 595. https://doi.org/10.1002/er.4440160703.

[28] Fagbenle, R.O. (1993). Total solar radiation estimates in Nigeria using a maximum-likelihood quadratic fit. Renewable Energy. 3, 813 - 817 . https://doi.org/10.1016/0960-1481(93)90089-Y

[29] Ituen, E.E., Esen, N.U., Nwokolo, S.C., Udo, E.G. (2012). Prediction of global solar radiation using relative humidity maximum temperature and sunshine hour in Uyo, in the Niger Delta Region, Nigeria Advances in Applied Research, 4, 1923 - 1937.

[30] Maduekwe AAL., Chendo M.A.C. (1999) Characteristics of the monthly average hourly diffuse irradiance at Lagos and Zaira, Nigeria Renewable Energy. 17: 213-225. https://doi.org/10.1016/S0960 1481(98)00034-2.

[31] Sambo, A.S. (1986). Empirical models for the correlation of global solar radiation with metrological data for Northern Nigeria. Solar Win Technology, 3, 89 - 93. https://doi.org/10.1016/0741-983X(86)90019-6.

[32] Nwokolo, S.C. (2017). A comprehensive review of empirical models for estimating global solar radiation in Africa. Renewable and Sustainable Energy Reviews, 78: 955-995 https://doi.org/10.1016/j.rser.2017.04.101.
[8] Liu, B.V.H., Jordan, R.C. (1960). The interrelationship and characteristics distribution of direct, diffuse and solar radiation. Solar Energy 4, 1 9. https://doi.org/10.1016/0038-092X(60)90062-1.

[9] Louche, A., Notton, G. Poggi., Simonnot, G. (1991). Correlation for direct normal and global horizontal irradiance on French Mediterranean site. Solar Energy. 46, 261 - 266. https://doi.org/10.1016/0038092X(91)90072-5.

[10] Maduekwe, A.A.L., Chendo, M.A.C. (1993). Empirical models in predicting the direct normal solar irradiance on a horizontal surface in Lagos. International Atomic Agency and United Nations Educational Scientific and Cultural Organisation, International Centre for Theoretica physics, 1-7.

[11] Maxwell, A.L. (1987). A quasi-physical model for converting hourly global horizontal to direct normal insolation. Report SERI/TR-215 3087, Solar Energy Research Institute, Golden, CO.

[12] Perez, R., Seals, R., Zelenka, A., Incichen, P. (1990). Climatic evaluation of models that predict hourly direct irradiance from hourly global irradiance: projects for performance improvements. Solar Energy. 47 99 - 108. https://doi.org/10.1016/0038-092X(90)90071-J.

[13] Vignola, F., McDaniels, D.K. (1986). Beam - global correlations in the Pacific Northwest. Solar Energy. 36, $409 \quad-418$ https://doi.org/10.1016/0038-092X(86)90088-5.

[14] Wenxian, A. (1988). A general correlation for estimating the monthly average daily direct radiation incident on a horizontal surface in Yunnan Province, China, Solar Energy. 41, 1-3. https://doi.org/10.1016/0038092X(88)90107-7.

[15] Maduekwe, A.A.L., Chendo, M.A.C. (1995). Predicting the components of the total hemispherical solar radiation from sunshine duration measurement in Lagos, Nigeria, Renewable Energy. 6 (7): 807-812 https://doi.org/10.1016/0960-1481(95)91008-2.

[16] ASHRAE handbook: HVAC application. Atlanta (GA): ASHRAE, 1999

[17] Davies, J.A., Mckay, D.C. (1984). Estimating solar irradiance and components. Solar energy. 29, 55 - 64 https://doi.org/10.1016/S0038092X(84)80049-3.

[18] Sherry, T.E., Justus, C.G., (1984). A simple hourly all-sky solarradiation model based on meteorological parameters. Solar energy. 32 195 - 204 https://doi.org/10.1016/S0038-092X(84)80036-5.

[19] Nfaoui, H. Buret, J. (1993). Estimation of daily and monthly direct, diffuse and global solar radiation in Rabat (Morocco). Renewable Energy, 3: 923-930 https://doi.org/10.1016/0960-1481(93)90052-I.

[20] Battles, F.J., Rubio, M.A., Touar, J., Olmo, J., Olmo, F.J., Alados - Arboledas, L. (2002). Empirical modelling of hourly direct irradiance by means of hourly global radiance. Energy. 25, 675 - 688 https://doi.org/10.1016/S0360-5442(00)00007-4.

[21] Nwokolo, S.C., \& Ogbulezie, J.C. (2017a). A single hybrid parameterbased model for calibrating Hargreaves-Samani coefficient in Nigeria. International Journal of Physical Research, 5(2): 49-59 https://doi.org/10.14419/ijpr.v5i2.8042.

[22] Willmott C.J. (1981). On the validation of Models. Journal of Physics and Geography. 2, $184-194$.

[33] Nwokolo, S.C., \& Ogbulezie, J.C., (2017b). A Quantitative Review and Classification of Empirical Models for Predicting Global Solar Radiation in West Africa. Beni-Suef University Journal of Basic and Applied Sciences, (In Press), https://doi.org/10.1016/j.bjbas.2017.05.001. 